\title{
Physical and chemical characterization of bioaerosols - Implications for nucleation processes
}

\author{
P.A. Ariya, J.Sun, N.A. Eltouny, E.D. Hudson, C.T. Hayes \& G.Kos
}

\begin{abstract}
The importance of organic compounds in the oxidative capacity of the atmosphere, and as cloud condensation and ice-forming nuclei, has been recognized for several decades. Organic compounds comprise a significant fraction of the suspended matter mass, leading to local (e.g. toxicity, health hazards) and global (e.g. climate change) impacts. The state of knowledge of the physical chemistry of organic aerosols has increased during the last few decades. However, due to their complex chemistry and the multifaceted processes in which they are involved, the importance of organic aerosols, particularly bioaerosols, in driving physical and chemical atmospheric processes is still very uncertain and poorly understood. Factors such as solubility, surface tension, chemical impurities, volatility, morphology, contact angle, deliquescence, wettability, and the oxidation process are pivotal in the understanding of the activation processes of cloud droplets, and their chemical structures, solubilities and even the molecular configuration of the microbial outer membrane, all impact ice and cloud nucleation processes in the atmosphere. The aim of this review paper is to assess the current state of knowledge regarding chemical and physical characterization of bioaerosols with a focus on those properties important in nucleation processes. We herein discuss the potential importance (or lack thereof) of physical and chemical properties of bioaerosols and illustrate how the knowledge of these properties can be employed to study nucleation processes using a modeling exercise. We also outline a list of major uncertainties due to a lack of understanding of the processes involved or lack of available data. We will also discuss key issues of atmospheric significance deserving future physical chemistry research in the fields of bioaerosol characterization and microphysics, as well as bioaerosol modeling. These fundamental questions are to be addressed prior to any definite conclusions on the potential significance of the role of bioaerosols on physico-chemical atmospheric processes and that of climate.
\end{abstract}

\section{Introduction}

Airborne particles or aerosols can directly and indirectly impact the Earth's climate. They can directly absorb and scatter radiation. Their indirect effect is linked to their ability to form or act as cloud condensation nuclei (CCN) and ice-forming nuclei (IN), and hence lead to the formation of clouds, thus indirectly influencing the Earth's radiation budget. Clouds play an important role through absorption of terrestrial infrared radiation and via reflection (albedo) of solar radiation, and minute variations in cloud albedo significantly modify the planetary albedo. Cloud albedo has been found to depend upon the properties of hydrometeors, such as their chemical composition, their size distributions, their phases and even their shapes in addition to their concentrations, and hence any perturbations in the properties of aerosols acting as CCN and IN can have a potential impact on the optical properties of clouds. These characteristics are key issues, which need to be addressed prior to understanding the link between aerosols, clouds, and ultimately climate. The properties of CCN and IN in the atmosphere also impact rain formation. Precipitation in turn regulates the wash-out of aerosols from the atmosphere. Therefore, aerosol particles have the potential to affect the water cycle, and even agriculture and human health due to their chemical properties 1 . It is imperative to characterize these nucleating inorganic and organic particles, which make up the total aerosol population and understand mechanistically the physicochemical process of cloud droplet activation and ice crystal nucleation (Figure 1), which highly impacts the processes of aerosol-cloud interactions. Aerosols are considered by the Intergovernmental Panel on Climate Change Report (IPCC, 2007) as a significant factor affecting the magnitude of climate change, deserving further research. 
This is the peer reviewed version of the following article: [P. A. Ariya, J. Sun, N. A. Eltouny, E. D. Hudson, C. T. Hayes \& G. Kos (2009) Physical and chemical characterization of bioaerosols - Implications for nucleation processes, International Reviews in Physical Chemistry, 28:1, 1-32, DOI: 10.1080/01442350802597438], which is accessible at:

https://www.tandfonline.com/doi/abs/10.1080/01442350802597438

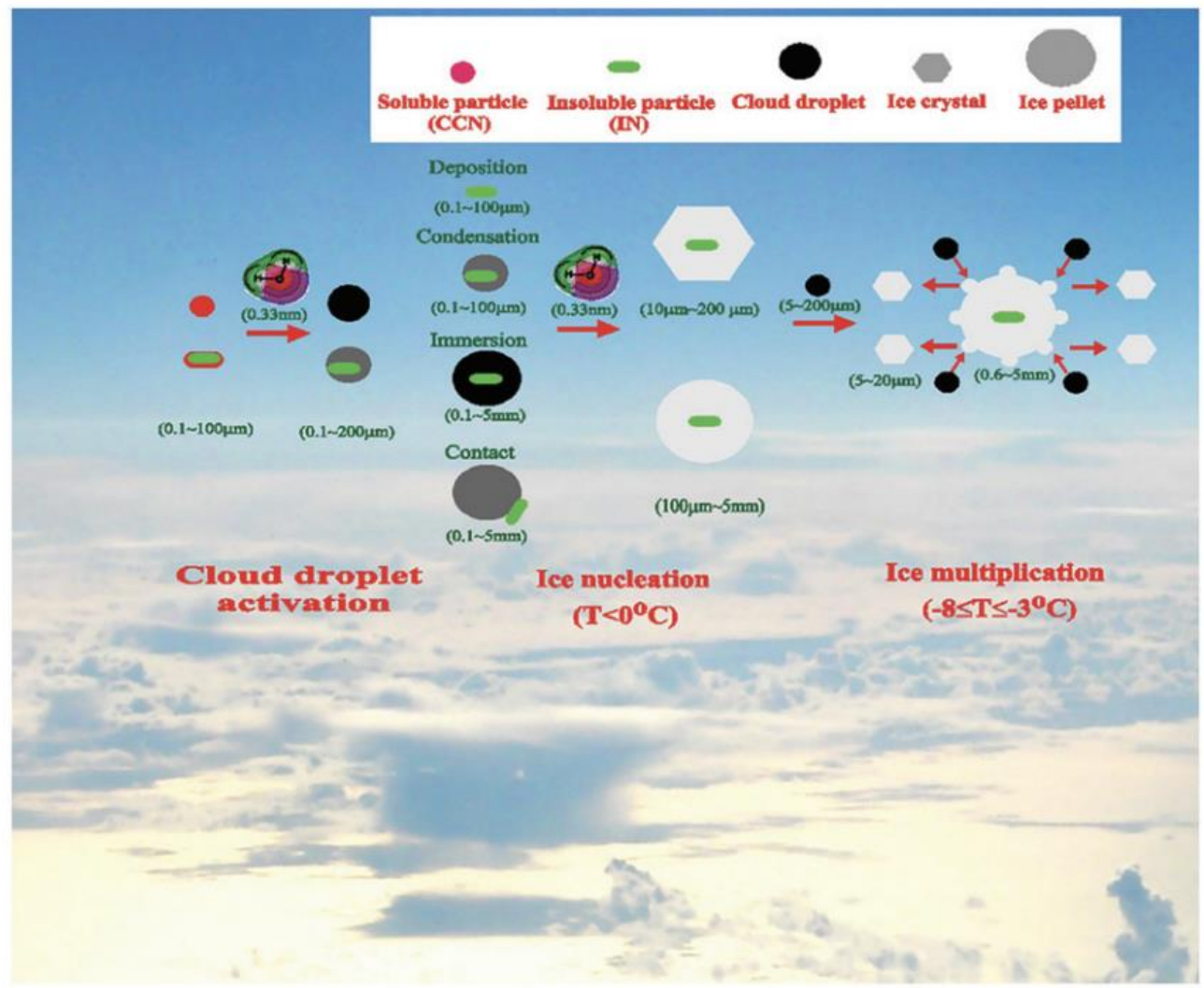

Figure 1. [Colour online] Characteristics of warm-based convective clouds (shown in background) and their recognized glaciation mechanism.

\subsection{Definitions}

Organic aerosols are an important, yet less understood, subgroup of aerosols. Material content is divided into elemental and organic carbon 2 and the latter are further classified into primary organic aerosols (POA) and secondary organic aerosols (SOA). While POA are directly emitted into the atmosphere by biogenic or anthropogenic sources, SOA result from the oxidation of natural or anthropogenic emissions such as volatile organic compounds (VOCs) which then condense on a particle or nucleate $\underline{3}$. Biogenic sources of POA include vegetation (e.g. waxes and essential oils from leaf surfaces), soil erosion, and oceans (e.g., organic material adsorbed on bubbles, or material from phytoplankton activity) 2 . Anthropogenic sources include organic emissions from residential or agricultural biomass burning and fossil fuel burning (residential, industrial and traffic) leading to the emission of medium and long chain hydrocarbons $\underline{2}$. Some classes of compounds, such as dicarboxylic acids and alcohols $\underline{2}, \underline{3}$ can have multiple, indistinguishable sources, originating from either biogenic or anthropogenic sources and being primary or secondary organic aerosols, making the set-up of a classification scheme without overlaps or ambiguities very difficult.

Bioaerosols are a subgroup of biogenic organic aerosols; they are airborne particles or large molecules, ranging from $10 \mathrm{~nm}$ to $100 \mu \mathrm{m}$ in diameter and very heterogeneous in nature. They can be alive, dead, dormant (e.g., bacteria, viruses and fungi), or products released from living organisms (e.g., metabolites, pollen, cell debris, and biofilms) $\underline{4}$. Since a lot of potential bioaerosol species, especially among the metabolites, could also originate from other primary or secondary biogenic sources (e.g. mannitol from the Tamarix gallica plant, but also common in fungi 5) a consistent classification of species is not possible, but has to be related to its source. Hence, bioaerosol species will contribute to the overall organic aerosol budget and so far it is not clear whether this contribution of atmospherically active species (organic compounds as well as microorganisms or parts thereof) is significant. 
This is the peer reviewed version of the following article: [P. A. Ariya, J. Sun, N. A. Eltouny, E. D. Hudson, C. T. Hayes \& G. Kos (2009) Physical and chemical characterization of bioaerosols - Implications for nucleation processes, International Reviews in Physical Chemistry, 28:1, 1-32, DOI: 10.1080/01442350802597438], which is accessible at:

https://www.tandfonline.com/doi/abs/10.1080/01442350802597438

\subsection{Objectives}

This review thus strives to provide an overview of the state-of-the-art in bioaerosol research concerning the chemical and physical characterization of species, and to discuss their potential impact on climate by way of acting as CCN and IN. Information on suitable methods of analysis used in previous studies for chemical and physical characterization as well as for the investigation of CCN and IN activity will be presented and the usefulness of the existing data for regional and global model studies will be investigated. Uncertainties and directions of future research will be discussed.

\subsection{Microorganisms in the atmosphere}

The presence of microorganisms in the atmosphere has been known for several centuries, notably through the early studies of Spallanzani and Pastor in the middle of the 18th and 19th centuries, respectively $\underline{6}$. From microbiological studies, there is much interesting early literature devoted to the identification of biological particles $\underline{7}$ and dedicated, targeted studies describing the field of aerobiology $\underline{8}, \underline{9}$. However, these aero microbiological studies did not include any physical or chemical perspectives, and it was not until the second half of the 20th century that particles of biological origin received renewed attention from physicists and chemists, who were interested in their implications for human health, agriculture, ice nucleation and cloud droplet activation, and ultimately atmospheric chemistry due to their ubiquity in the atmosphere. Until recently, microbiological, physical and chemical research proceeded along very separate, parallel paths, and closer interactions have only developed over the last decade $\underline{6}$. These will potentially lead to an increased multidisciplinary understanding of the physical chemistry of biological particles in the atmosphere ( $\underline{6}$ and articles in a 2008 special issue of Biogeosciences on 'Properties of Biological Aerosols and their Impact on Atmospheric Processes'). The presence of various types of bioaerosols in indoor air, the troposphere and even the stratosphere, has long been established (e.g. 10). Some recent works have indicated that about $25 \%$ of the particles suspended in air (by mass) are primary organic aerosols of biological origin 11. Over the Amazon, Graham et al. 12 have observed that ca $74 \%$ of the aerosol volume (or mass) consists of biological particles. Jaenicke 13 has estimated that the major sources of particles in Earth's atmosphere (desert, oceans, and the biosphere) contribute equally to the bioaerosol budget, underlining the potential importance of bioaerosols for climatic processes, provided their modes of action and role as CCN and IN is properly understood. The abundance of bioaerosols is also subject to significant temporal and spatial variation as a function of altitude, region (e.g., rural, urban, forest, ocean) and meteorological factors including temperature, radiation, relative humidity, rainfall, and wind speed and direction $\underline{6}$. Significant daily and seasonal variations have also been observed. For instance, high concentrations of airborne bacteria and fungal spores frequently occur from spring to fall in temperate regions $\underline{6}$, possibly due to leaf surfaces being a major source of airborne fungi $\underline{14}, \underline{15}$ and bacteria $\underline{16}$. Even over a single day, the airborne spore concentration has been observed to increase from 20,000 to 170,000 spores $/ \mathrm{m}^{3}$ in a 2-hour period in the area around Tulsa, Oklahoma (USA) 17. We note that not all aerial microorganisms show a strong diurnal variation; for instance, airborne concentrations of the fungus Gibberella zeae showed no difference between the day and night at $60 \mathrm{~m}$ above the ground $\underline{18}$.

Many different taxa of airborne microorganisms have been observed. Both gram-positive bacteria (those that retain the color of the crystal violet stain in the gram stain test), and gram-negative bacteria have been commonly observed in the atmosphere $\underline{9}, \underline{19}, \underline{20}$. Although most identified airborne bacteria are assumed to be of the more robust grampositive type, gram-negative bacteria (assumed to be more fragile) have also been frequently detected. Among the fungi, spores similar to those from Cladosporium, Aspergillaceae, Alternaria, Botrytis, and various Basidomycetes (Coprinus, Ustilago) have been frequently observed in the atmosphere $\underline{6}, \underline{9}, \underline{19}$. Spores of Cladosporium spp. seem to be numerically the most dominant. Other biota such as viruses have also been observed in the atmosphere, namely over the sea-surface $\underline{21}$.

The airborne particles may be present as single spores or clusters. In some cases these are covered with mucus-like material 20,22, which supports the suggestion that chunks or remnants of microbial biofilms offer these taxa both a means of take-off and survival in the air 23 . Little is known about the properties of these particles and their transport 
This is the peer reviewed version of the following article: [P. A. Ariya, J. Sun, N. A. Eltouny, E. D. Hudson, C. T. Hayes \& G. Kos (2009) Physical and chemical characterization of bioaerosols - Implications for nucleation processes, International Reviews in Physical Chemistry, 28:1, 1-32, DOI: 10.1080/01442350802597438], which is accessible at:

https://www.tandfonline.com/doi/abs/10.1080/01442350802597438

mechanism in the air, while being essential not only for their survival. Environmental conditions can favor the presence of one organism over another; for instance, an acidic $\mathrm{pH}$ favors the presence of fungi and spore-forming bacteria whereas a neutral $\mathrm{pH}$ favors a greater diversity of microorganisms 24 . Over land, aerial parts of plants are a principal source of airborne microorganisms $\underline{20}$. It is also speculated that microorganisms are also released into the atmosphere even under calm conditions if microbial growth leads to population sizes exceeding the physical carrying capacity of the plant surface $\underline{6}$.

\subsection{Reactivity of bioaerosols}

Bioaerosols are not necessarily inert particles, and biological processes should theoretically affect the extent and the magnitude of the physical and chemical processes that these particles undergo while in the atmosphere. Biological particles are suggested to have properties that allow them to act as ice nuclei or cloud condensation nuclei $\underline{4}$ and to participate in radiative forcing $\underline{13}$. Bioaerosols' number density (e.g., $\sim 10^{3}-10^{4}$ bacteria/ $\mathrm{m}^{3}$ ) is the same order of magnitude as that of other ice nuclei, hinting at the potential significance of bioaerosols as effective IN $\underline{25}$. Several types of biological organisms and their debris have been identified as effective CCN $\underline{25}$. Some also produce highly active ice nuclei that may be involved in processes that lead to precipitation $\underline{4}, \underline{26}$. In addition, much of the airborne microbial flora likely metabolizes chemical components of aerosols thereby potentially modifying atmosphere chemistry $\underline{4}$. Furthermore, non-metabolic processes such as adsorption of molecules from biological surfaces 27 , chemical release due to cell lyses, and collision-coalescence processes can drive adsorption and desorption from cellular surfaces, modifying the chemical composition of atmospheric gas-phase and particulate matter. Chemical reactions dictate the lifetime of atmospheric particles, their ability to act as cloud condensation nuclei or ice nuclei. Physical and chemical processes govern the total mass of airborne particles, their acidity, and the amount of light they scatter and absorb, their reactivity, and their ability to act as cloud condensation nuclei $\underline{6}$. Airborne distribution is part of the natural life cycle of many microorganisms and has likely occurred since their emergence on this planet; therefore, their adaptation to conditions in the atmosphere has had potential consequences on microbial population genetics and genome structure $\underline{6}$. Biologists are now becoming involved in nucleation studies. Many investigations have determined that bioaerosols are important players in atmospheric chemistry $\underline{28}, \underline{29}$, including nucleation, both as nuclei themselves and by transforming non-biological nuclei 27 . A proper understanding of the physical chemistry of bioaerosols should also include studies in microbiology and meteorology.

There are several articles on aerobiology and the importance of meteorological factors, chemical composition, cloud coverage, rainfall, dust storms, and the $\mathrm{pH}$ of aerosols, to the occurrence and the variability of air flora (e.g. $\underline{6}, \underline{20}, \underline{30-}$ $\underline{33}$ ). A number of reviews have discussed the physical properties of organic and bioaerosols acting as CCN $\underline{25}, \underline{34}$ and the role of biological particles acting as IN $\underline{34}, \underline{35}$.

In the following sections we report the present state of knowledge, including microphysics and chemistry of ice and cloud condensation nucleation by bioaerosols (Section 2), the tools providing information on the physical and chemical characteristics (Section 3) of bioaerosols, and the high-risk, emerging field of bioaerosol modeling (Section 4). We focus on the chemical and physical properties that are critical to determining their impact on precipitation and climate, through the nucleation of cloud droplets and ice and as a consequence through direct or indirect aerosol radiative forcing (Section 5). We will discuss the major uncertainties on characterization and nucleation processes focusing on biological and organic matter that are to be further studied, and their potential impact on climate.

\section{Nucleation processes}

Nucleation is a process involving the phase change from a less dense to a more condensed phase. In a system, which is thermodynamically favored for a phase change (e.g. a liquid below its melting temperature, or a vapor above its saturation level), an activation energy barrier exists which can keep the system in its meta-stable state. A new surface or nucleus must be created within the bulk phase on which the new phase can grow. Nucleation is the random aggregation of particles that provides this new surface, pushing the system over the kinetic barrier to phase change. 
This is the peer reviewed version of the following article: [P. A. Ariya, J. Sun, N. A. Eltouny, E. D. Hudson, C. T. Hayes \& G. Kos (2009) Physical and chemical characterization of bioaerosols - Implications for nucleation processes, International Reviews in Physical Chemistry, 28:1, 1-32, DOI: 10.1080/01442350802597438], which is accessible at:

https://www.tandfonline.com/doi/abs/10.1080/01442350802597438

\subsection{Cloud condensation and ice nucleation}

In order to form cloud droplets from homogeneous water vapor, a supersaturation of several hundred percent is necessary. In the atmosphere, supersaturations rarely exceed $10 \%$, and usually stay below $1 \%$. Cloud droplet formation thus primarily occurs heterogeneously. Aerosol particles, called cloud condensation nuclei (CCN), act as catalysts $\underline{36}$. These particles can be characterized by the supersaturation at which they become active (through deliquescence if water-soluble) and form droplets. The supersaturation, $S$, of vapor over a solution droplet, with radius $r$, was described first by Köhler 37 with the equation:

$$
S=\frac{P}{P_{\mathrm{o}}}-1=a_{\mathrm{w}} \exp \left(\frac{2 \sigma M_{\mathrm{w}}}{r \rho R T}\right)-1
$$

With

$$
a_{\mathrm{w}}=\frac{m_{\mathrm{w}}}{m_{\mathrm{w}}+i m_{\mathrm{s}}\left(M_{\mathrm{w}} / M_{\mathrm{s}}\right)}
$$

where $P$ is the water vapor pressure over the droplet, $P_{\mathrm{o}}$ is the water vapor pressure over a flat water surface, $\sigma$ is the surface tension of the solution droplet, $\rho$ is the water density, $R$ is the gas constant, $T$ is temperature, and $a$ w is the water activity, calculated through the masses and molecular masses of the solute and water $\left(m_{\mathrm{s}}, m_{\mathrm{w}}, M_{\mathrm{s}}, M_{\mathrm{w}}\right)$ and $i$, the Van't Hoff factor. Equation (1) combines the Raoult effect (described in the $a_{\mathrm{w}}$ term) of a decrease in vapor pressure over a solution, and the Kelvin Effect (described by the exponential) of vapor pressure increase over surfaces of great curvature. This is generally a good description for water-soluble inorganic salt particles. Many variations on this equation, primarily concerning the water activity term, have been made in order to increase its applicability and generality. Recently, Varga et al. $\underline{38}$, stressing the poor performance of this theory for organic particles, measured osmolalities of organic solutions, from which a more accurate water activity can be derived $\underline{39}$.

The CCN ability of organic compounds is determined by many factors such as van't Hoff factor variation with the concentration of solute and solubility, solubility, surface tension, volatility, morphology, contact angle, deliquescence, and oxidation process $\underline{14}$. There is still no comprehensive formula to describe all these impact factors. The impact of impurity, solubility, and surface tension on the activation of organic particles can be seen from the hygroscopic growth of a slightly soluble organic acid (adipic acid) simulated by a modified Köhler equation $\underline{14}$ (Figure 2). An illustrative example of hygroscopic bioaerosol is the pollen grain. Diehl et al. $\underline{40}$ have found that many pollen species can uptake upwards of $100 \%$ of their weight in water in humid air $(95 \% \mathrm{RH})$. Surface Raman spectroscopy of pollen grains show a definitive peak at $1274 \mathrm{~cm}^{-1}$, indicative of either, $=\mathrm{CH}$ in plane (lipid) or amide III (protein) modes, peaks at 806 , 846 , and $894 \mathrm{~cm}^{-1}$, attributable to different $\mathrm{C}-\mathrm{N}$ stretch modes of tyrosine groups, in addition to other peaks affording more tenuous assignments of $\mathrm{C}=\mathrm{C}$ groups, $\mathrm{COO}^{-}$groups, and $\mathrm{C}-\mathrm{H}$ or $\mathrm{N}-\mathrm{H}$ bends of lipids and proteins $\underline{41}$.

Figure 2. [Colour online] Variation of supersatuation as a function of droplet size for adipic acid at 298.15 K. The following curves consider: (a) classical Kohler equation (van't Hoff factor $i=1$ ), (b) Kohler equation considering surface tension change, (c): Kohler equation including limited solubility with equation, (d) Kohler equation including limited solubility with $2 \%$ mass fraction of ammonium sulfate. 
This is the peer reviewed version of the following article: [P. A. Ariya, J. Sun, N. A. Eltouny, E. D. Hudson, C. T. Hayes \& G. Kos (2009) Physical and chemical characterization of bioaerosols - Implications for nucleation processes, International Reviews in Physical Chemistry, 28:1, 1-32, DOI: 10.1080/01442350802597438], which is accessible at:

https://www.tandfonline.com/doi/abs/10.1080/01442350802597438

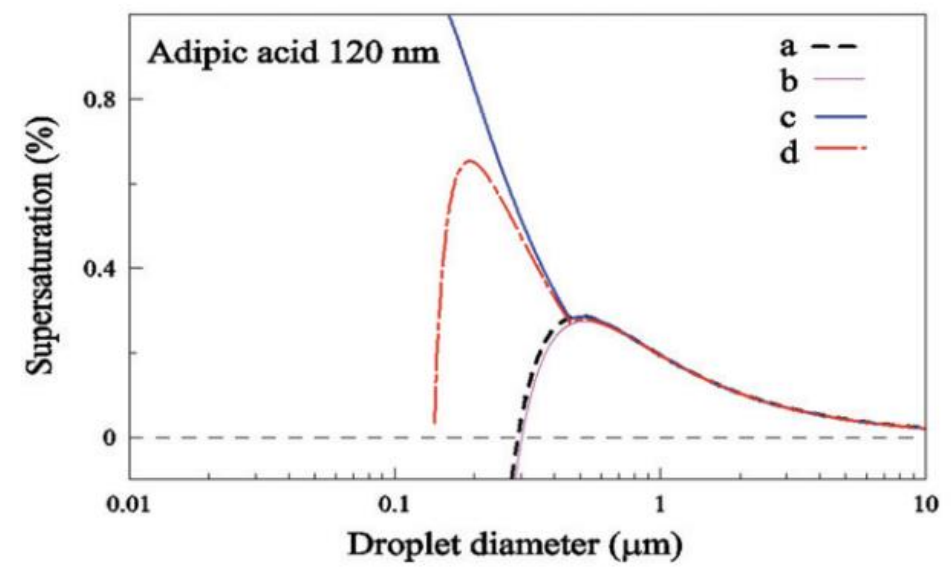

Figure 2. [Colour online] Variation of supersatuation as a function of droplet size for adipic acid at $298.15 \mathrm{~K}$. The following curves consider: (a) classical Kohler equation (van't Hoff factor $i=1$ ), (b) Kohler equation considering surface tension change, (c): Kohler equation including limited solubility with equation, (d) Kohler equation including limited solubility with $2 \%$ mass fraction of ammonium sulfate.

By analogy with $\mathrm{CCN}$, ice nuclei (IN) are required to complete the liquid-solid or vapor-solid transition. Ice nucleation can occur in four modes in the atmosphere: deposition, condensation-freezing, immersion, and contact 42. Ice does not form homogeneously without a supercooling of about $35 \mathrm{~K}$ from liquid or at very high vapor supersaturations 43,44 . In the atmosphere, these conditions are usually absent, except in haze particles or cirrus and other high tropospheric clouds 45 . Hence, ice nucleation is often heterogeneous. Nonetheless, organic aerosols nucleate ice via both heterogeneous and homogeneous mechanisms. The melting temperature and solubility of organic compounds affect which nucleation mechanism operates 46 . Normally longer chain organic compounds will induce heterogeneous ice nucleation due to their high melting temperatures. Factors influencing the heterogeneous ice nucleation ability of a particle include size, surface activity (through $\mathrm{H}$-bonding or adsorption), and a water-like lattice structure 35 .

There have been fewer quantitative descriptions of a particle's effect on ice nucleation than on cloud condensation nucleation. Turnbull and Vonnegut used the free energy (or activation energy) of heterogeneous nucleation ( $\left.\Delta G_{\text {nucl }}\right)$ to describe the nucleation process of IN 47.

$$
\Delta G_{\text {nucl }}=\frac{16 \pi f(\theta) \gamma_{\mathrm{sl}}^{3}}{3\left(\Delta G_{\mathrm{f}}\right)^{2}}
$$

With

$$
f(\theta)=\frac{(2+\cos \theta)(1-\cos \theta)^{2}}{4}
$$

where $\theta$ is the wetting or contact angle against solid substrate, $\gamma_{\mathrm{sl}}$ is the solid-liquid interfacial energy, $\Delta G_{\mathrm{f}}$ is the free energy of fusion, and $k$ is the Boltzmann constant. The function $f(\theta)$ arises from geometrical considerations of a spherical cap-shaped nucleus. Equation ( $\underline{3}$ ) also holds for homogeneous nucleation with $f(\theta)=1$. The solid-interfacial energy (Equation $\underline{3}, \gamma_{\mathrm{sl}}$ ) is difficult to calculate theoretically and is usually left as an adjustable parameter $\underline{42}$. Since nucleation occurs under non-equilibrium conditions, the temperature dependence of $\Delta G_{\mathrm{f}}$ must be accounted for. To this end, the free energy of fusion has been substituted with the entropy of fusion, $\Delta S_{\mathrm{f}}$ (Equation $\underline{5}, \underline{47}$ ) or the enthalpy of fusion, $\Delta H_{\mathrm{f}}($ Equation $\underline{6}, \underline{48})$. These substitutions are made on the assumption that, over small ranges of 
This is the peer reviewed version of the following article: [P. A. Ariya, J. Sun, N. A. Eltouny, E. D. Hudson, C. T. Hayes \& G. Kos (2009) Physical and chemical characterization of bioaerosols - Implications for nucleation processes, International Reviews in Physical Chemistry, 28:1, 1-32, DOI: 10.1080/01442350802597438], which is accessible at:

https://www.tandfonline.com/doi/abs/10.1080/01442350802597438

temperature, enthalpy and entropy are independent of temperature. All that said, although the activation energy of ice nucleation must depend on the kinetic argument of the solid-interfacial energy and thermodynamic argument of the energy of fusion, there has been no consensus on the correct mathematical expression of $\Delta G_{\text {nucl }}$ and theory has been essentially stagnant since Equation ( $\underline{3})$ 's publication.

$$
\begin{gathered}
\Delta G_{\mathrm{f}} \cong\left(T_{\mathrm{m}}-T\right) \Delta S_{\mathrm{f}} \\
\Delta G_{\mathrm{f}} \cong \frac{T_{\mathrm{m}}}{\left(T_{\mathrm{m}}-T\right) \Delta H_{\mathrm{f}}}
\end{gathered}
$$

where $T$ is temperature and $T_{\mathrm{m}}$ is melting temperature. Much experimental work has probed the IN ability of organic aerosols and bioaerosols, which can provide some insights into the behavior of bioorganic aerosols in ice nucleation. Ice nucleation experiments on bioorganic particles have been reviewed in a recent paper 34 . This section provides a broad overview of experimental studies of organic compounds and the major advances and difficulties of ice nucleation experiments.

\subsection{Ice-nucleating activity of bioaerosol compounds}

Early studies of organic IN were conducted on solid organic compounds in order to find active IN for cloud seeding. A thorough and systematic investigation of bioaerosols has not yet been undertaken due to the heterogeneity of this compound group. We will explicitly point out any relevance for bioaerosol species in this and other sections. Since organic metabolites make up a significant fraction of smaller bioaerosols, the behavior of organic compounds similar to these metabolites can be to be similar to those of bioaerosols, provided these compounds are released into the atmosphere by biological processes. Phloroglucinol, $\mathrm{C}_{6} \mathrm{H}_{3}(\mathrm{HO})_{3}$, was the first organic IN discovered 49. During the 1960s, the ice-forming properties of some aromatic compounds 50 and steroids 51 were examined, the latter already being an indication that complex biochemical species might be active IN. Head 52,53 found that thermal cracks were active sites for ice nucleation, as demonstrated through epitaxy 54, i.e., the growth of one crystal in one or more specific orientations on a chemically different, but geometrically similar, crystal substrate. Power and Power 55 have reported that some amino acids are active ice nuclei, thus demonstrating the ability of biogenic compounds and bioaerosols to be potentially active in nucleation processes. For amino acids this is indeed possible, if they are available in the atmosphere, released from cell debris of plant, bacteria or fungi. In fact, the effectiveness of the well known bacterial ice nucleus, $P$. syringae (an insoluble bioaerosol), is partially attributed to its cell wall, containing a certain repetition of amino-acids which acts as a template for ice formation due to its pseudo-hexagonal symmetry 56 .

Fukuta 57 found that oxalic acid and adipic acid (dicarboxylic acids, DCA) could act as ice nuclei at -10 and $-9^{\circ} \mathrm{C}$, respectively, and that about 47 of 329 compounds could be active above $-3^{\circ} \mathrm{C}$. Fletcher 58 later applied contactnucleation tests to over 1000 organic compounds at $-3^{\circ} \mathrm{C}$. The fact that DCA are able to act as IN is of particular relevance since it has been shown that these species can act as nutrients for bacteria and fungi 27 , with the latter changing the overall number of IN available.

Drops covered by monolayers of aliphatic long-chain alcohols $\left(\mathrm{C}_{n} \mathrm{H}_{2 n+1} \mathrm{OH}\right)$ have been observed to freeze at small supercoolings, even near $-1^{\circ} \mathrm{C} 59,60$. For $n$ monolayers $(n \leq 31)$ nucleation temperatures were higher for odd values of $n$ than for even values. For even values of $n$, the highest observed nucleation temperatures reached $-8^{\circ} \mathrm{C}$ (for $n$ > 22). For odd values of $n$, the nucleation temperatures gradually rose to near $-1^{\circ} \mathrm{C}$. Alcohols have also been identified as being metabolites of microbiological species and as being bioaerosol components 27,61 , although a direct link between release from microorganisms and IN activity has not yet been established. In comparison, carboxylic acids of similar chain lengths produced ice nucleation at temperatures around $-16^{\circ} \mathrm{C}$. Lattice match of properties of an IN and ice may be important, but it is neither a necessary nor a sufficient condition for effective ice nucleation. Other factors can also lead to good nucleating ability. Nikandrov 62 has suggested that the mechanism of nucleation on organics may differ from that of inorganic substances. Gavish et al. 63 confirmed ice-nucleating ability for some amino acids, which have a very poor lattice fit with ice. They thus proposed that electric fields within cracks of crystals 
This is the peer reviewed version of the following article: [P. A. Ariya, J. Sun, N. A. Eltouny, E. D. Hudson, C. T. Hayes \& G. Kos (2009) Physical and chemical characterization of bioaerosols - Implications for nucleation processes, International Reviews in Physical Chemistry, 28:1, 1-32, DOI: 10.1080/01442350802597438], which is accessible at:

https://www.tandfonline.com/doi/abs/10.1080/01442350802597438

raised nucleation temperatures. Visual observations confirmed that cracks were preferred locations, for deposition nucleation at $-15^{\circ} \mathrm{C}$.

Recently, scientists have paid more attention to the ice nucleating efficiencies of atmospheric organic aerosols. It has been suggested that atmospheric particles with high organic content with low melting temperatures are not efficient IN 64; a possible explanation is that the organic compounds change the water activities of inorganic compounds 65. Pure dicarboxylic acids, which can be of biogenic origin and are certainly metabolized by microorganisms, are not as efficient ice nuclei as sulfate particles of the same size 66. The involvement of water-soluble organic compounds can affect the water uptake of internal mixed aerosols of ammonium sulfate with dicarboxylic acids 67. Laboratory experiments have shown that maleic acid can act as IN in deposition nucleation mode 68 . Furthermore, the dihydrate of oxalic acid can nucleate ice heterogeneously in immersion freezing mode 69.

In summary, there is substantial evidence that heterogeneous IN activity is more predominant among polar or latticefit organic species with high crystallization ability, but a fully comprehensive theory capable of predicting icenucleating ability of organic compounds and bioaerosols has yet to be suggested. However, recent observations have shown that ice nucleation can be initiated quickly by oxidized aerosol coated with sulfate in more polluted regions of clouds 70, suggesting that organic compounds play an important role in ice crystal formation in the atmosphere.

Notwithstanding the knowledge gained from experiment, ice nucleation research presents some difficulties in producing environmentally relevant results. These difficulties, discussed in the next section, must be addressed in order to evaluate bioaerosols' impact on the physical chemistry of atmospheric processes.

\subsection{Experimental difficulties in ice nucleation research}

In addition to four primary modes of nucleation (deposition, condensation-freezing, immersion, and contact), secondary mechanisms complicate the issue further; e.g., the 'riming-splintering' process can occur, in which small shattered ice crystals can promulgate ice formation 71. The different modes of nucleation, as they occur in the atmosphere, are related to different cloud processes and play different roles in cloud glaciation. Therefore, ice nucleation experiments are the fundamental studies to investigate cloud glaciation processes not only related to ice nuclei, but also related to nucleation modes. This presents a choice in experimental ice nucleation research: to isolate modes and extrapolate to atmospheric processes or to recreate atmospheric conditions and interpolate the separate modes. DeMott 72 provides a critical investigation of the four modes of ice nucleation of AgI aerosols via cloud chamber experiments. More studies focusing on bioaerosols as nuclei, and the separation of the nucleation modes are needed in lieu of a general, qualitative description of the ice nucleation process induced by organic compounds presumed to be of biological origin.

Table 1 presents the result of several experimental studies on the ice nucleation potential of different particles, illustrating how bioaerosols compare to a number of abiotic ice nucleators. Freezing temperatures can vary significantly with nucleation mode. However, within a few degrees, freezing temperatures for the same nuclei measured by different techniques agree. While mean freezing temperatures are a great simplification of the complex process of nucleation, they nonetheless provide a first approximation of nucleation potential and allow for quantitative comparison, especially in a field which lacks a standard measuring technique. Results reported in the present work were obtained using the drop-freezing technique described by Vali 73. Other techniques employ cloud-chamber like systems, or other methods of observing individual droplets such as a free-fall tube or levitating device. 
This is the peer reviewed version of the following article: [P. A. Ariya, J. Sun, N. A. Eltouny, E. D. Hudson, C. T. Hayes \& G. Kos (2009) Physical and chemical characterization of bioaerosols - Implications for nucleation processes, International Reviews in Physical Chemistry, 28:1, 1-32, DOI: 10.1080/01442350802597438], which is accessible at:

https://www.tandfonline.com/doi/abs/10.1080/01442350802597438

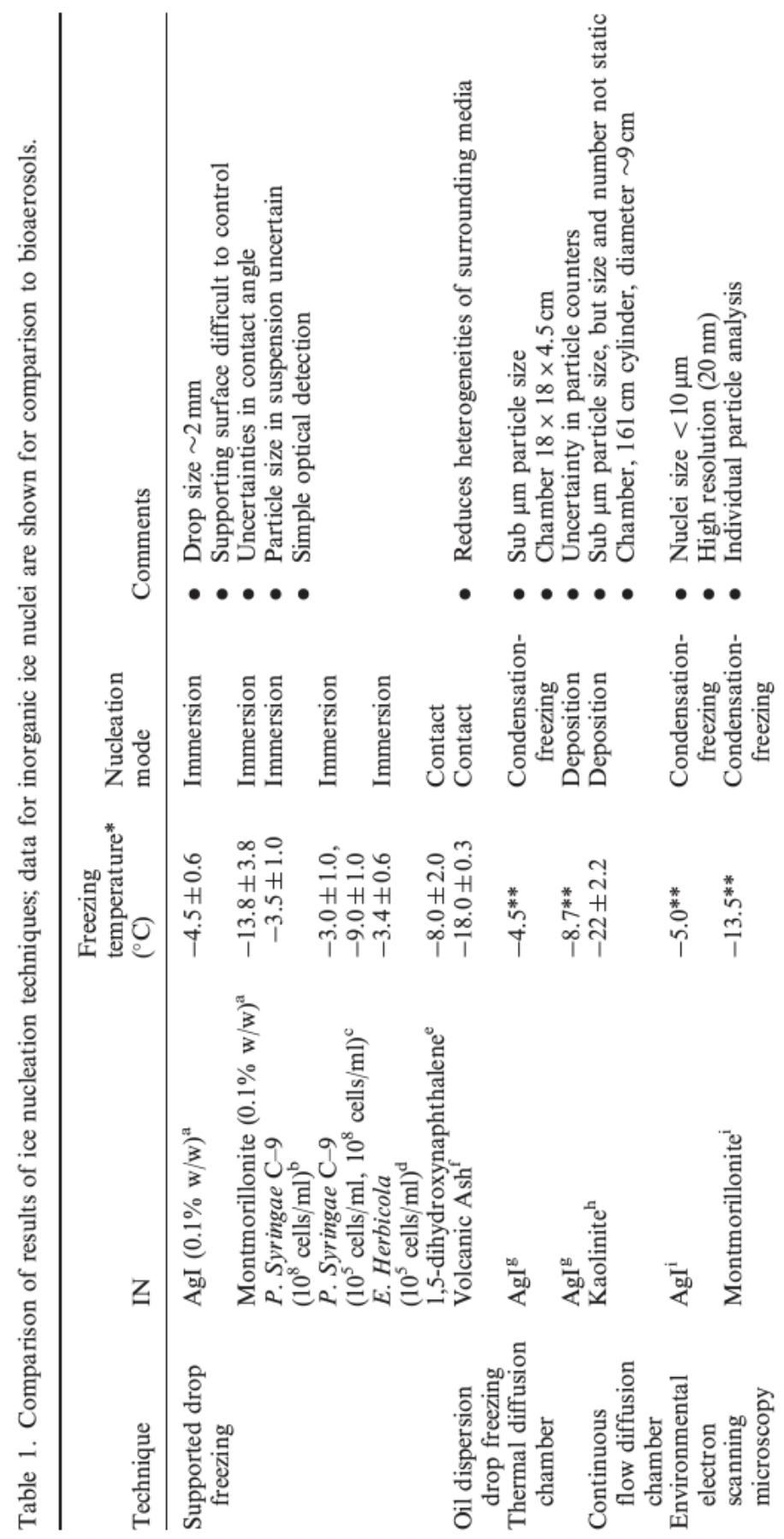


This is the peer reviewed version of the following article: [P. A. Ariya, J. Sun, N. A. Eltouny, E. D. Hudson, C. T. Hayes \& G. Kos (2009) Physical and chemical characterization of bioaerosols - Implications for nucleation processes, International Reviews in Physical Chemistry, 28:1, 1-32, DOI: 10.1080/01442350802597438], which is accessible at:

https://www.tandfonline.com/doi/abs/10.1080/01442350802597438

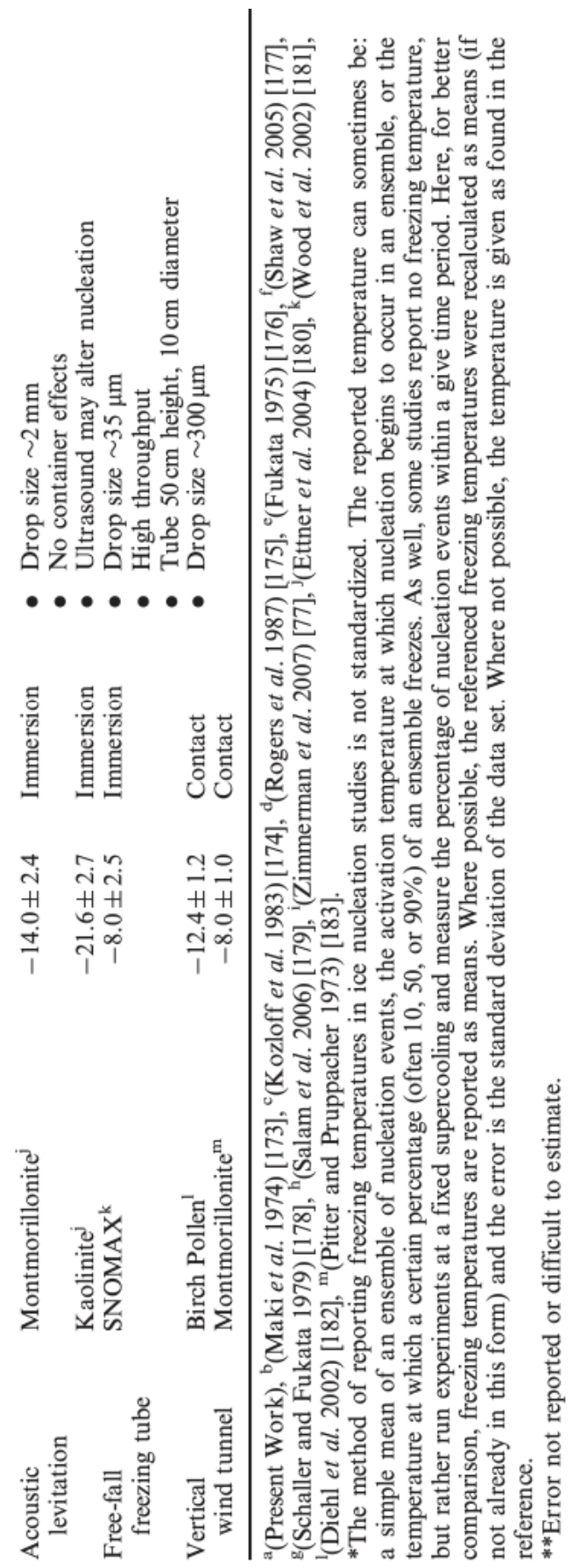

A subtle bifurcation can be seen in the choice of nucleation techniques: creating a cloud-like situation (droplet size $10-50 \mu \mathrm{m})$ in diffusion chamber type experiments, or more of an 'individual drop isolation', isolating specific nucleation events using larger drop sizes (droplet size 300-2000 $\mu \mathrm{m}$ ). The first choice offers more atmospherically relevant freezing conditions including a wide range of water saturations and temperature, and the ability to monitor CCN abilities in addition to IN. Nonetheless, this approach relies on particle counters or light scattering to detect 
This is the peer reviewed version of the following article: [P. A. Ariya, J. Sun, N. A. Eltouny, E. D. Hudson, C. T. Hayes \& G. Kos (2009) Physical and chemical characterization of bioaerosols - Implications for nucleation processes, International Reviews in Physical Chemistry, 28:1, 1-32, DOI: 10.1080/01442350802597438], which is accessible at:

https://www.tandfonline.com/doi/abs/10.1080/01442350802597438

frozen droplets and information on individual nucleation events is lost. The second choice can offer more insight into specific nucleation processes with creative experimental design (e.g. monitoring single drop freezing in levitation or free-fall techniques). However, the resolution of single events is obtained at the expense of using less atmosphericallyrelevant drop sizes. Also, the means of single drop isolation can sometimes introduce more uncertainties or completely alter the nucleation process. For instance, the polarization of water molecules in drops levitated electrodynamically $\underline{74}$ alters nucleation in uncertain ways. Additionally, ultrasonically levitating drops introduces a new mode of nucleation, sono-crystallization, which is not well understood 75 .

In addition to the bifurcation of scales (individual droplets vs. large ensembles of droplets) in nucleation experiments is the separation between phenomenological accounts of the nucleation and chemical/molecular accounts. Indeed, the studies of aerosols that act as atmospheric nuclei have been largely physically or microphysically oriented. One can then make inferences about the efficiency and mechanism of nucleation on a particle surface based on the results of nucleation experiments with some knowledge what the particle's surface should look like (e.g. knowing its bulk chemical formula). On the other hand, there is a striking paucity of chemical characterizations of the particles, which induce nucleation during the process of nucleation. We can ascribe a particle's nucleating ability to ice-related symmetry, as in the case of the proteins lining the cell wall of $P$. Syringae, however, we cannot yet write molecular equations describing the complex diffusion-adsorption-nucleation process without better knowledge of the surfaces inducing nucleation and the forces in operation during the process. Advances in colloid and surface science, including single particle characterizations using laser mass spectrometry $\underline{76}$, Raman spectroscopy $\underline{41}$ and electron microscopy $\underline{77}$ will help mitigate the gap between chemical and phenomenological accounts of nucleation.

It is clear that, as of yet, no experimental approach simultaneously offers a complete investigation of the nucleation process itself and the role of nucleation in clouds. Both approaches complement each other and should continue.

\subsection{Properties affecting the CCN activity of bioaerosols}

Organic matter has been reported to influence the hygroscopicity of aerosol particles, allowing them to exhibit $\mathrm{CCN}$ activity. The question becomes to what extent and how accurately can this hygroscopicity be attributed to bioaerosols? The following section will deal with the physicochemical properties of organic aerosols, which influence hygroscopicity.

\subsubsection{Hygroscopicity: WSOC}

Hygroscopicity is the ability of the nuclei to condense water vapor to form aqueous solutions at very low equilibrium vapor pressure relative to pure water at the same temperature and thereby activating the condensation nuclei at lower relative humidity 78 . It has been attributed to the organic aerosols and to the water soluble organic (WSOC) fraction in particular $\underline{79}$, which makes up to $11-95 \%$ of the organic fraction $\underline{80}$. The solubility of the compounds making up the organic fraction (which includes fungal spores and bacteria $\underline{81}$ ), affects their hygroscopic character; soluble or hydrophilic compounds being able to take up water and facilitate the formation of droplets $\underline{82}$. In fact, the water soluble fraction was reported to consist of highly polar sugars (fructose, glucose, sucrose, trehalose) and sugar alcohols (arabitol, inositol, mannitol), which are tracers for primary bioaerosols, pollen and fungi, respectively $\underline{80}$. Pollen grains, which are hydrophilic, have been reported to be $\mathrm{CCN} \underline{83}$. A group of biopolymers, cellulose material from plant debris, was also found in atmospheric aerosol $\underline{84}$ and contributes to the WSOC $\underline{85}$. Other biopolymers, macromolecules similar to naturally occurring humic substances (HUmic-LIke Substances - HULIS) also make up part of WSOCs $\underline{85}$ (55-60\% in the high level range or 13-36\% in the low level range) and influence hygroscopic growth by decreasing the surface tensions $\underline{79}$, in turn lowering the supersaturation critical diameter $\underline{86}$ and exhibiting CCN activity. These groups can result from photooxidation of biogenic emissions (isoprene emitted from vegetation) $\underline{87}, \underline{88}$ although they do not result from these exclusively. 
This is the peer reviewed version of the following article: [P. A. Ariya, J. Sun, N. A. Eltouny, E. D. Hudson, C. T. Hayes \& G. Kos (2009) Physical and chemical characterization of bioaerosols - Implications for nucleation processes, International Reviews in Physical Chemistry, 28:1, 1-32, DOI: 10.1080/01442350802597438], which is accessible at:

https://www.tandfonline.com/doi/abs/10.1080/01442350802597438

\subsubsection{Hygrosocopicity: wettability}

Hygroscopic growth also occurs in the presence of hydrophobic particles such as bacteria $\underline{89}$. Studies on bacterial CCN activity show diameter increases of 34 and $16 \%$ at relative humidity $>85 \%$ for E.coli and B. subtilis 89 . Low solubility particles (e.g., bacteria $\underline{89}$ ) can take up water if their contact angle with water is zero $\underline{90}, \underline{91}$. Measuring the latter determines wettability, the ability to spread water over a surface (low water contact angle), which depends on the surface tension of the solid and the wetting substance. Contact angles for bacteria are reported to be lower than 30 degrees $\underline{92}$ or even lower than 16 degrees $\underline{25}$ allowing them to be CCN active despite being generally hydrophobic $\underline{89}$. Studies report that, even for bacteria of the same species, varying degrees of hydrophilicity exist and it is suggested that properties (composition, structure and hydrophilicity) of the outer cell surface layer are influential in $\mathrm{CCN}$ activity 89 . So far, studies have been concentrated on bacteria and their potential impact on CCN activity of aerosols for which the understanding of water uptake remains incomplete $\underline{34}$.

\subsubsection{Activity coefficient}

Bioaerosols can undergo reactions in the atmosphere as aging (oxidation) and change the chemical composition. Organic miscibility in the bulk water and interactions between organics, inorganic salts, and water can be determined by the activity coefficient $\underline{2}, \underline{93}$. The latter has been measured experimentally using EDB and scanning electrodynamic balance (SEDB) 94; however, measurements for WSOC remain challenging in part due to their high volatility 94 . An alternative approach provides estimations using thermodynamic models such as UNIFAC $\underline{93}, \underline{95}$, which has been used for organic aerosol systems, and can be adapted to account for new organic or ion functional groups by adding new parameters 95 . Because the model depends on functional group knowledge, incomplete understanding of organic mixtures' composition $\underline{96}$ as well as the close proximity of highly polar multifunctional groups $\underline{93}$ (small dicarboxylic acids) 94 limit the model. Those limitations can be relevant when dealing with bioaerosols, since they consist of highly polar sugars, sugar-alcohols $\underline{80}$. However, it is not yet clear to what extent these models can be adapted for the treatment of bioaerosols.

\subsubsection{Atmospheric processes}

Atmospheric processes such as oxidation, nitration, photolysis and hydrolysis also affect the organic aerosol composition 97 . The uptake of oxidants $\left(\mathrm{O}_{3}, \mathrm{NO}_{3}, \mathrm{OH}\right)$, one form of aging $\underline{98}$, has been linked to increased solubility due to larger chains of soluble multifunctional groups formation $\underline{82}, \underline{99}$. Measurements, however, have yet to be made to establish a clear attribution between increased bulk solubility and aging 98 . Azaleic acid, the oxidation product of oleic acid (emitted from microbial sources), has been detected in high concentration in aerosols over a forest in Germany 100 . The understanding of the aging process, however, remains incomplete as field data and laboratory measurements do not always overlap 98 due to different preparation methods of the aerosol mixture system 101 which dictate the morphology of the particle itself affecting the uptake coefficient measured $\underline{98}, \underline{101}$ or difficulty in reproducing atmospheric conditions (use of different time scales and concentrations) 98 .

Properties of bioaerosols such as WSOC fraction and low contact angle allow them to act as CCN. The understanding of behavior as $\mathrm{CCN}$, however, is still incomplete as measurements can sometimes be limited by the varying physical (solubility, high volatility, polarity etc.) and chemical (composition) properties, which are dependent on atmospheric ambient conditions as well as biological properties.

\section{Chemical, physical and biological characterization of bioaerosols}


This is the peer reviewed version of the following article: [P. A. Ariya, J. Sun, N. A. Eltouny, E. D. Hudson, C. T. Hayes \& G. Kos (2009) Physical and chemical characterization of bioaerosols - Implications for nucleation processes, International Reviews in Physical Chemistry, 28:1, 1-32, DOI: 10.1080/01442350802597438], which is accessible at:

https://www.tandfonline.com/doi/abs/10.1080/01442350802597438

We here outline methods for the physical and chemical characterization of bioaerosols. Methods for determining many of the relevant properties of bioaerosols are summarized in Table 2, which outlines the advantages and shortcomings of some major techniques. We focus particularly on means of analyzing those properties that can determine or distinguish material of biogenic or biological origin, on studies of naturally occurring aerosols (rather than laboratory model systems), and on those properties of relevance to ice and cloud nucleation.

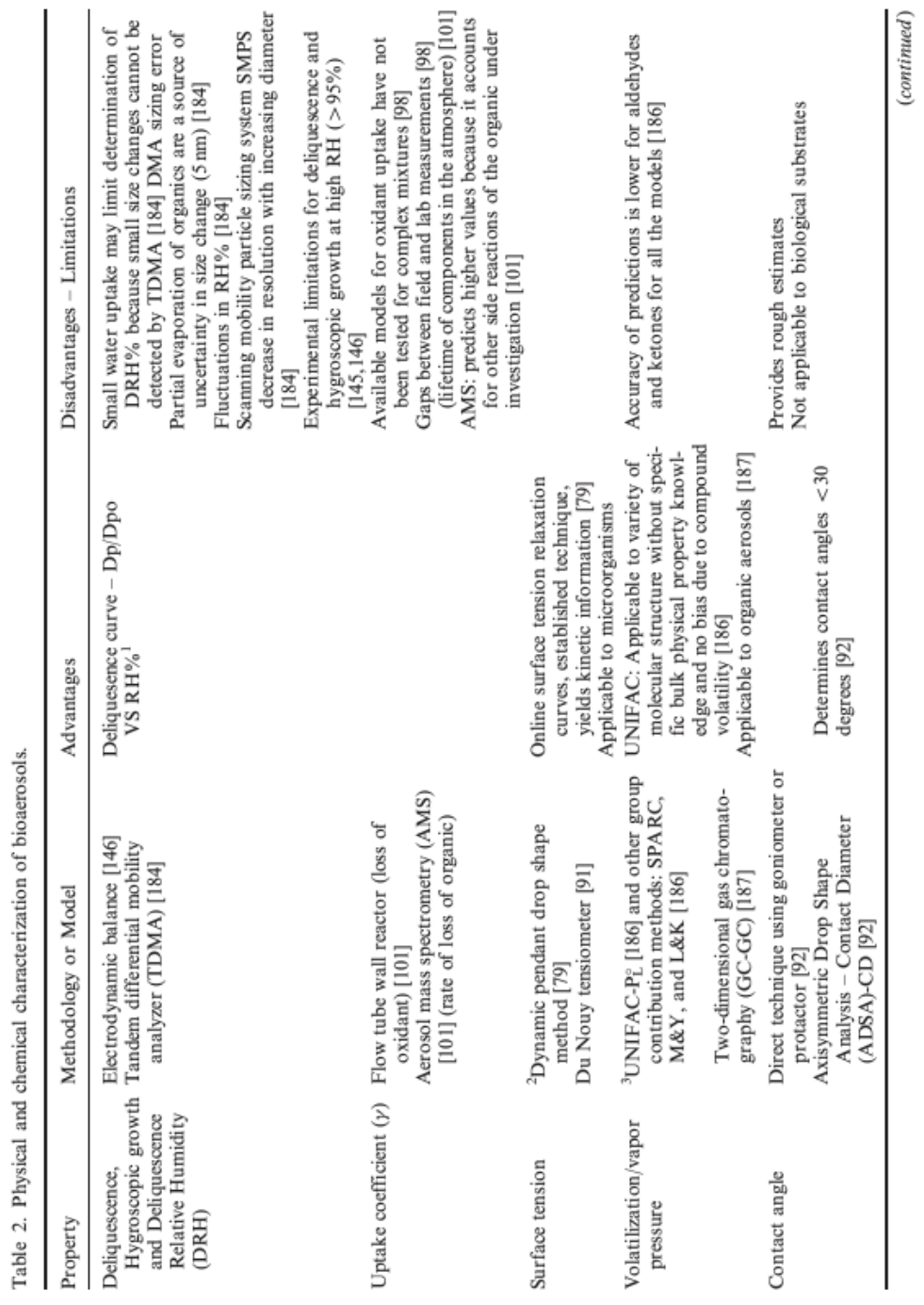


This is the peer reviewed version of the following article: [P. A. Ariya, J. Sun, N. A. Eltouny, E. D. Hudson, C. T. Hayes \& G. Kos (2009) Physical and chemical characterization of bioaerosols - Implications for nucleation processes, International Reviews in Physical Chemistry, 28:1, 1-32, DOI: 10.1080/01442350802597438], which is accessible at:

https://www.tandfonline.com/doi/abs/10.1080/01442350802597438

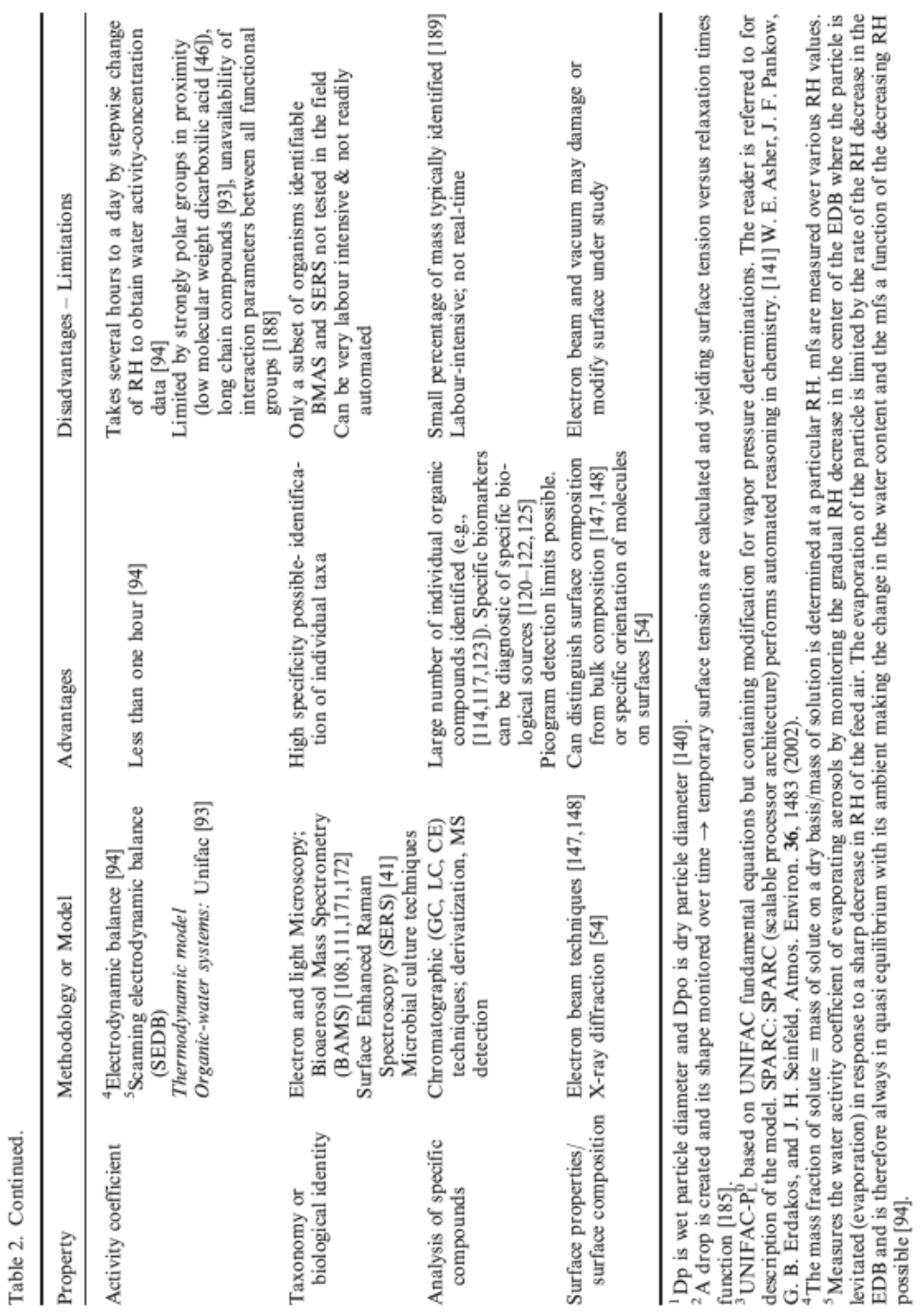

\subsection{Microbiological characterization, identification and taxonomy}

A number of biological and chemical methods can identify intact microbiota which may constitute bioaerosols The microbiological characterization of bioaerosols has been recently described by Georgeakopoulos et al. 102 . In short, classic isolation techniques on nutrient media have been widely used to enumerate and characterize airborne bacteria and fungi $\underline{81}, \underline{89}$. Biological particles are collected by impaction on a filter or an agar surface and, after incubation, visible developed colonies are enumerated and subsequently identified. Immunological detection has also been widely used to detect microorganisms of medical or phytopathological significance. Antibodies isolated from the serum of an inoculate can be used as a means for detection of a number of different microorganisms. In flow cytometry, size, shape, and selected biological properties can be measured simultaneously. Adenosine triphosphate (ATP) levels can be used as a measure of viability of microorganisms in environmental matrices such as clouds $\underline{24}$. The polymerase chain reaction (PCR) has revolutionized microbial ecology by facilitating the direct analysis of nucleic acids in any sample. It is used to copy, many million-fold, specific regions of the genome (typically <1000 bases), providing enough material for analyses. Often $<100$ target molecules are a sufficient template for a successful amplification, and a single bacterium or fungal spore can be detected in fully optimized reactions. 
This is the peer reviewed version of the following article: [P. A. Ariya, J. Sun, N. A. Eltouny, E. D. Hudson, C. T. Hayes \& G. Kos (2009) Physical and chemical characterization of bioaerosols - Implications for nucleation processes, International Reviews in Physical Chemistry, 28:1, 1-32, DOI: 10.1080/01442350802597438], which is accessible at:

https://www.tandfonline.com/doi/abs/10.1080/01442350802597438

Morphology may also be readily used to indicate a biological origin. Scanning (SEM) and Transmission Electron Microscopy (TEM) can reveal the distinct morphologies of biological particles including bacteria 103,104 , fungal spores and pollen grains 103,105 and brochosomes 106. Larger bioaerosols such as pollen grains can readily be analyzed by light microscopy (e.g., 107). Both electron and light microscopies are typically labour-intensive and difficult to automate when used for these purposes.

A number of other methods have been reported to distinguish bioaerosols from abiotic aerosols and to classify the latter. A recently-developed Bioaerosol Mass Spectrometer (BAMS) 108-110 uses time-of-flight (TOF) mass analysis and laser ionization for real-time detection of specific microorganisms, distinguishing different Bacillus species based on mass spectra with low $\mathrm{m} / z(<200)$ fragments $\underline{109}$, and vegetative cells form spores $\underline{110}$. A similar TOF-based system 111 distinguishes bacteria from inorganic particles by laser-induced tryptophan fluorescence, and provides mass spectra (up to $85 \mathrm{kDa}$ ) of the bacteria. Rosch et al. 112 sampled aerosols by impaction, used fluorescence to identify which particles were bacteria, and then Raman microspectroscopy to identify these. By adding colloidal silver to bioaerosol samples, Sengupta et al. 41 similarly reported distinctive surface enhanced Raman spectra of different bacterial taxa and pollen species. It is not yet known how effective these techniques will be when deployed in the field.

\subsection{Analysis of individual compounds: characterization of sources and composition}

Specific chemical compounds in aerosols can be used to attribute a biological origin to them, but are also potentially important to their behavior as CCN or IN (Section 2.2.). Liquid Chromatography (LC) and Gas Chromatography (GC), especially with mass spectrometric (MS) detection, can identify and quantify many specific compounds in aerosol samples, which indicate or suggest a biological origin. GC has been especially widely used for organic aerosols $\underline{113}-$ $\underline{121}$ and many molecular markers characteristic of biogenic material have been identified (examples below), allowing source assignment or partitioning. Detection limits for individual compounds in the low $\mathrm{pg} / \mathrm{m}^{3}$ range are typical $116, \underline{122}$, and extract fractionation, and/or the use of extracted ion chromatograms typical of particular compound classes, allow many individual overlapping compounds in very complex mixtures to be analyzed $\underline{116}$. Pio and co-workers $\underline{114}, \underline{117}, \underline{123}$ have identified up to 1050 individual organic compounds in aerosol samples from South European sites, including vegetation-derived alcohols and phenolic compounds, organic acids, phytosterols, and long chain alkanes and alkanones The Carbon Preference Index (CPI) (ratio of total odd- to even- carbon-number long chain alkanes) can indicate a higher plant source of organic matter $\underline{114}, \underline{115}, \underline{117}, \underline{120}$. Patterns of long-chain alkanes and alcohols $\underline{124}$ and biomass burning products $\underline{125}$ analyzed by GC-MS can indicate terrestrial biological material in marine aerosols. Distinct molecular markers, along with distinctive patterns of common compounds, can be attributed to burning of biomass e.g., levoglucosan from cellulose $\underline{118}, \underline{125}$, abietic, pimaric and dehydroabietic acids 120 to distinguish hardwood from softwood burning, and distinctive patterns of phenolic and syringyl compounds from combustion of jackfruit branches $\underline{121}$. Chemometric statistical techniques such as positive matrix factorization (PMF) 126 may increase the information available from molecular markers, allowing source apportionation, including of the biogenic fraction. More hydrophilic organic components of aerosols, such as sugars and sugar polyols $\underline{80}, \underline{127}$ and terpene oxidation products $\underline{128}, \underline{129}$, are often better analyzed by LC or capillary electrophoresis. LC-MS detection limits of tens of pg 130 are possible for sugars which are characteristic of plant bioaerosols 80. Capillary Electrophoresis/Mass Spectrometry (CE-MS) quantified $38 \mathrm{C}_{5}-\mathrm{C}_{10}$ organic acids in atmospheric particles 131 and was used to analyze HULIS $\underline{132}$. Atmospheric mono- and di-carboxylic acids, some of which are from plants sources $\underline{133-135}$, and which are potential cloud nucleators $\underline{136}$, are typically analyzed by ion chromatography (IC) (e.g. 137,138). Chromatographic methods are often labour-intensive, requiring solvent extraction, extract fractionation, and (for GC) derivatization (e.g. 113,114,116,118,125) of certain compound classes before chromatography. Furthermore, chromatographic data are not obtained in real time, but are averaged over, often, lengthy sampling times. Finally, since analyses must be often be conducted on a pooled sample, no information is available concerning the partitioning of particular substances on specific sizes or shapes of particles.

Puxbaum and Tenze-Kunit have developed $\underline{139}$ and used $\underline{139}, \underline{140}$ an enzymatic method for cellulose in aerosols, which can be applied directly to a sample from filters or impactor plates, without pre-fractionation or chromatography. 
This is the peer reviewed version of the following article: [P. A. Ariya, J. Sun, N. A. Eltouny, E. D. Hudson, C. T. Hayes \& G. Kos (2009) Physical and chemical characterization of bioaerosols - Implications for nucleation processes, International Reviews in Physical Chemistry, 28:1, 1-32, DOI: 10.1080/01442350802597438], which is accessible at:

https://www.tandfonline.com/doi/abs/10.1080/01442350802597438

Laser-induced fluorescence (LIF) studies by Pinnick, Pan and co-workers 141,142 identified spectral features of HULIS and of tryptophan, likely from microbial sources, in large $(>1 \mu \mathrm{m})$ organic atmospheric particles.

\subsection{Molecular weight}

The molecular weight of substances in aerosols influences colligative properties and therefore influences surface tension and ionic strength 143,144 . LC-MS and vapor pressure osmometry 143 have been used to determine average molecular weights of atmospheric HULIS. Ultraviolet absorbance has also been correlated with HULIS molecular weight $\underline{88}$. These studies reported number-averaged molecular weights (MN) of 215-345 Da 143 and 410-610 Da $\underline{145}$.

\subsection{Hygroscopicity and wettability (contact angle)}

Hygroscopicity influences the CCN behavior of bioaersols. Measurements of hygroscopic growth have been carried out with electrodynamic balance (EDB) single particle levitation, where relative mass determinations are done at various relative humidities $\underline{146}$, and with a Tandem Differential Mobility Analyzer (TDMA), which measures and selects particles according to their size based on their mobility in an electric field making such measurements before and after humidification indicated the degree of aerosol hygroscopicity. Low water contact angles, such as those of bacteria, have been measured by modified Axisymmetric Drop Shape Analysis (ADSA) 92.

\subsection{Surface characterization and heterogeneity}

Since ice nucleation takes place on the surfaces of aerosols (Sections 2.1-2.2), identification of surface composition or compositional heterogeneity of bioaerosols is valuable. Energy-dispersive X-ray spectroscopy (EDX) showed an organic layer on sea salt aerosols to be carbon and oxygen rich $\underline{147}$. Using TOF secondary ion mass spectrometry the layer was further shown to consist of marine lipids 148 , postulated to originate from biological material in the sea surface microlayer. The lipid layer has important implications for the hygroscopicity of these particles. The importance of lattice match to ice nucleation on organic compounds has been previously noted (Section 2.1); grazing-incidence $\mathrm{X}$-ray diffraction (GID) was used to study alcohols and acids on surfaces $\underline{54}$, confirming the importance of epitaxy.

\section{Ice nucleation modeling of bioaerosols in cumulus clouds}

Cloud modeling study is an important way to apply experimental and observational results to evaluate the potential importance of physical and chemical processes leading to the cloud nucleation. It is noteworthy that the numerical modeling studies, if done adequately, can indeed constrain the major uncertainties, and evaluate the importance of the processes in cloud nucleation. As a dominant class of ice nuclei at relatively warm temperatures, bioaerosols should play an important role in ice formation in clouds, especially in warm-based precipitating cumulus clouds. However, complicated compositions of bioaerosols and their theoretically unknown nucleation microphysics mechanism make the explicit simulation of ice nucleation by bioaerosols impossible in any cloud models. Therefore parameterization methods based on laboratory experiments of nucleation efficiencies of different IN are necessary to simulate the ice nucleation process of bioaerosols 149 . For example, ice-nucleating bioaerosols covered with liquid water in supercooling conditions may catalyze the freezing of supercooled water drops. However, this process is mainly determined by nucleation properties of bioaerosols, which are poorly understood, in addition to the volume of water drops, supercooling rate, and subfreezing temperatures. It is thereby necessary to establish the relationship between nucleation rates of bioaerosols as a function of various environmental conditions during the laboratory experiments, 
This is the peer reviewed version of the following article: [P. A. Ariya, J. Sun, N. A. Eltouny, E. D. Hudson, C. T. Hayes \& G. Kos (2009) Physical and chemical characterization of bioaerosols - Implications for nucleation processes, International Reviews in Physical Chemistry, 28:1, 1-32, DOI: 10.1080/01442350802597438], which is accessible at:

https://www.tandfonline.com/doi/abs/10.1080/01442350802597438

and parameterize the results for incorporation in modeling studies. Diehl and Wurzler 149 have developed parameterization methods to describe the nucleation process of bioaerosols $\underline{149}$. In this section, the potential importance of bio-aerosols in cumulus cloud glaciation, as assessed using cloud modeling studies with parameterization methods, will be reviewed.

As one kind of bioaerosols, bacteria have been identified in clouds and fog $\underline{150}, \underline{151}$, raindrops $\underline{152}, \underline{153}$ as well as hailstones 154 . The concentration of airborne bacterial cells varies with the time of day, altitude, location and season $\underline{16}, \underline{151}, \underline{155}, \underline{156}$ from 1 per liter to more than 1000 per liter. Ice-nucleating bacteria have been widely identified in air, rain and hail $\underline{157}$, and certain species of active ice-nucleating bacteria have been observed at heights of up to 6 $\mathrm{km} \underline{158}, \underline{159}$. Constantinidou et al. $\underline{160}$ found $5.5 \%$ of the total bacteria present in rain and in aerosols to be active as IN at temperatures warmer than $-10^{\circ} \mathrm{C}$ and $4.4 \%$ of them active at the temperatures warmer than $-5^{\circ} \mathrm{C}$. As the most active ice nuclei in nature, they exist widely on earth. Effective ice nucleation ability has been observed in more than ten different genera.

However, the limited knowledge about mechanisms of aerosol-cloud interaction and the complexity of ice nucleating properties and of spatial distribution of ice-nucleating bioaerosols, hamper our understanding of their role in cloud formation. Although bioaerosols show high ice nucleation efficiencies, their important role is easily overlooked compared with other aerosols due their low concentrations (due partly to the difficulties associated to their measurement) and complex properties in the atmosphere. The physical processes governing bioaerosol behavior in clouds are not understood. This is particularly the case in warm-based precipitating shallow cumulus clouds that we will examine in the next paragraphs, even though the primary ice crystals formed by ice-nucleating bioaerosols are not prominent compared with the total ice crystals in cumulus clouds.

The role of biological particles in cloud physics has received increasing attention recently $\underline{34}, \underline{161}$. Cloud modeling studies are one important approach to clarify the role of bioaerosols in cloud formation. Diehl et al. 161 simulated the insolubility effect of aerosols on cloud formation using a simple cloud parcel model. In this model, the insoluble part of an aerosol can represent different aerosols with different ice-nucleating efficiencies, such as bacteria, pollen, leaf debris and dust. Their modeling studies showed different cloud properties arising from different insoluble aerosols in the cloud. However, they could not demonstrate definitive effects of biological aerosol particles on cloud formation processes due to several challenges. Firstly, the biological aerosol characterization implemented in the model was not necessarily in accordance with measurements (e.g. extremely high concentrations of biological aerosols were used). Secondly, a simple cloud model driven by buoyancy may not correctly treat the evolution of cloud droplets. Lastly, the more sophisticated microphysics schemes for ice multiplication processes were not adopted. Recognizing these challenges, we encourage further systematic studies on the role of biological aerosols in cloud formation.

Recently, Sun et al. have developed an one-and-a-half-dimensional (1.5D) non-hydrostatic convective cloud and aerosol interaction model (NCCAIM) to test complex liquid-phase and ice-phase microphysical processes $\underline{162}$. A description of the treatment of the microphysics and dynamic processes in this model is given by Sun et al. 162 . A brief description of this case study is given in the appendix. We used this model with a different initial profile of icenucleating bacteria to examine their importance, or lack thereof, in the glaciation of warm-based precipitating shallow cumulus clouds. Preliminary results indicate that ice-nucleating bioaerosols can trigger the glaciation of warm-based precipitating shallow cumulus clouds $\underline{162}$. In a moderate convective cloud simulation, as illustrated in Figure 3 , the convection process and cloud formation occur in the low troposphere with the cloud top temperatures less than $-15^{\circ} \mathrm{C}$. We notice that the cloud is totally glaciated in the subfreezing level in its dissipating stage. Figure 4 shows the concentration evolution of ice crystals and ice-nucleating bacteria. The concentration of small ice particles increases from about 0.01 to $100 \mathrm{~L}^{-1}$ in less than 10 minutes. The maximum concentration of ice particles containing bacteria reached to the value of $3 \mathrm{~m}^{-3}$. This value includes both primary ice crystals nucleated by bacteria (present at a concentration of $10 \mathrm{~m}^{-3}$ ) as well as secondary crystals that scavenged bacteria. These results indicate that icenucleating bioaerosols can trigger the glaciation of warm-based precipitating cumulus clouds through the ice multiplication process $\underline{163}$. However, further targeted studies are required to examine this hypothesis. 
This is the peer reviewed version of the following article: [P. A. Ariya, J. Sun, N. A. Eltouny, E. D. Hudson, C. T. Hayes \& G. Kos (2009) Physical and chemical characterization of bioaerosols - Implications for nucleation processes, International Reviews in Physical Chemistry, 28:1, 1-32, DOI: 10.1080/01442350802597438], which is accessible at:

https://www.tandfonline.com/doi/abs/10.1080/01442350802597438

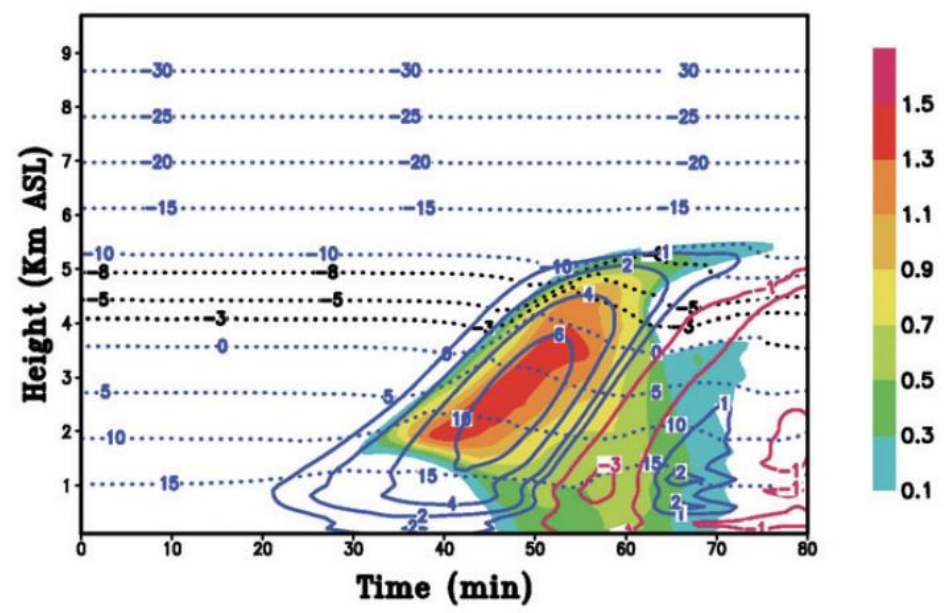

Figure 3. Temperature $\left({ }^{\circ} \mathrm{C}\right)$ (dotted line), vertical velocity $\left(\mathrm{m} \mathrm{s}^{-1}\right)$ (blue and red line) and rain water content (diameter $>100 \mathrm{~mm}$ ) (in $\mathrm{g} \mathrm{m}^{-3}$ ) (shaded area) as a function of time and height.

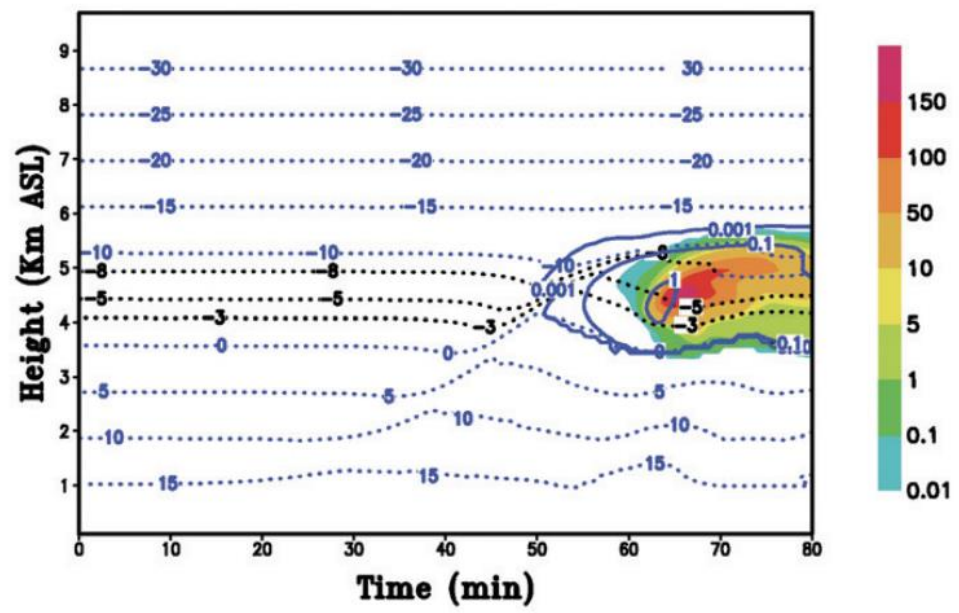

Figure 4. Temperature $\left({ }^{\circ} \mathrm{C}\right)$ (dotted line), ice crystal concentration $\left(\mathrm{L}^{-1}\right)$ (shaded area) and ice crystals containing bacteria $\left(\mathrm{m}^{-3}\right)$ (blue line) as a function of time and height.

Cumulus clouds are ubiquitous in the troposphere, and ice multiplication processes have always been observed in them. However the potential impact of ice nucleating bioaerosols on cloud glaciation is being ignored in present aerosol-cloud-climate interaction studies. At this stage, we know the potential significance of ice nucleation by bioaerosols on cloud glaciation process in some cumulus clouds. However, the indirect effect of bioaerosols in Earth's radiation budgets requires much further studies including research involving all kinds of clouds.

\section{Global estimates of the effect of bioaerosols on the radiative budget of the atmosphere: major uncertainties}

In order to make sound predictions of the impact of organic and bioaerosols on the radiation budget of the atmosphere, reliable global estimates of the type and the abundance of organic aerosols (mass and number density) are needed. Since bioaerosols contribute to the organic carbon estimates, they should contribute to the radiative forcing, which 
This is the peer reviewed version of the following article: [P. A. Ariya, J. Sun, N. A. Eltouny, E. D. Hudson, C. T. Hayes \& G. Kos (2009) Physical and chemical characterization of bioaerosols - Implications for nucleation processes, International Reviews in Physical Chemistry, 28:1, 1-32, DOI: 10.1080/01442350802597438], which is accessible at:

https://www.tandfonline.com/doi/abs/10.1080/01442350802597438

according to the IPCC 2007 is reported to be $-0.5 \pm 0.4 \mathrm{~W} / \mathrm{m}^{2}$ for the direct effect and $-0.7 \mathrm{~W} / \mathrm{m}^{2}$ (range -1.1 to +0.4 $\mathrm{W} / \mathrm{m}^{2}$ ) for the indirect effect and has a level of scientific understanding deemed medium-low 164.

To what extent do bioaerosols contribute to the radiative forcing? One of the quantities required to estimate their contribution is the emission flux. One of the difficulties in determining global estimates of the organic carbon budget is the absence of a direct technique to quantify $\underline{165}$ or differentiate between POA and SOA components $\underline{90}$. One reason for which bioaerosols' source determination is lacking is that some bioaerosol tracers, such as cellulose and protein, can be directly emitted by natural processes or result from human activity (waste storage and agriculture) $\underline{166}$. These issues result in significantly different global estimates of bioaerosol emissions, for instance, of $10 \mathrm{Tg} / \mathrm{yr} \underline{166}, 56$ $\mathrm{Tg} / \mathrm{yr} \underline{167}$ and up to $1000 \mathrm{Tg} / \mathrm{yr} \underline{83}$. Combined uncertainties in emissions of POA and SOA precursors result in an uncertainty factor between 2 and $5 \underline{82}$, affecting significantly the accuracy with which OA's impact on radiative forcing of the Earth's atmosphere can be assessed. Hence, the extent to which bioaerosols contribute to radiative forcing remains difficult to predict, source apportioning being one of the main challenges.

\section{Future research directions}

A multidisciplinary approach is required to understand the role of bioorganic aerosols in the atmosphere. The physical and chemical processes involving atmospheric bioorganic particles cannot be fully understood without considering other concomitant processes driven, for instance, by microbiology or meteorology. Although the existing data suggest a clear potential for bioaerosols to play important roles in both the physics and chemistry of the atmosphere, the uncertainties are so substantial that any definite conclusions would be premature at this stage. The list of uncertainties is long; the following are selected domains of research deserving further studies:

- There is a need to accurately and selectively measure various forms of bioaerosols, including measuring their fluxes. Measurements of total (and specific types of) biological particle concentration, viable microbial concentration, condensation or ice nuclei, binding sites or metabolic sources and sinks for various atmospheric chemicals, etc., are needed. Many of the most common techniques for biogenic aerosol characterization to date have been bulk methods, which can analyze for specific substances or functional groups, and identify aerosols' origin, history and chemical characteristics. However, they cannot analyze morphology, surface characteristics, and mixing state of size-resolved individual particles, and furthermore are generally unable to follow aerosol transformations in the field in real time. To further our understanding of the role of bioaerosols in climatically relevant processes, techniques are needed which can routinely report on these characteristics, preferably in real time, under ambient conditions. Certain AMS methods $\underline{168-170}$ fulfill or are approaching these requirements, and will need to be made more accessible in terms of cost and portability. BAMS $\underline{108}, \underline{111}, \underline{171}, \underline{172}$ is still in development but has the potential to identify biological particles in real time, in the field. It may become more valuable to climatically-related bioaerosol studies if our understanding of the IN or CCN properties of specific microbial taxa develops further, which will again require studies of their surface characteristics and chemistry.

- In order to assess the atmospheric nucleation potential of bioaerosols, the process of atmospheric nucleation itself still needs to be elucidated. We can neither theoretically nor experimentally separate the four modes of nucleation to explain the present observations of ice crystals in the atmosphere. Bioaerosols have the potential to act via any of the modal mechanisms. To determine which mode is predominant, or the way in which several modes are dynamically related, would be a huge leap forward in the understanding of their function in cloud processes and climate forcing. Barring the development of a comprehensive theory or the emergence of universally accepted experimental technique, the complementary experimentation of cloud-chamber like systems and 'single-drop' systems, such as levitation, should continue to offer alternative means of moving forward the state of knowledge of atmospheric nucleation by bioorganic aerosols. 
This is the peer reviewed version of the following article: [P. A. Ariya, J. Sun, N. A. Eltouny, E. D. Hudson, C. T. Hayes \& G. Kos (2009) Physical and chemical characterization of bioaerosols - Implications for nucleation processes, International Reviews in Physical Chemistry, 28:1, 1-32, DOI: 10.1080/01442350802597438], which is accessible at:

https://www.tandfonline.com/doi/abs/10.1080/01442350802597438

- The field of bioaerosol physical chemistry is very complex and at early stages in its evolution. There are several open issues, namely: (a) the contribution of airborne taxa to the transformation of inorganic compounds including trace metals in the atmosphere or at environmental interfaces, as well as the feedback of both oxidation and reduction of metals on the biological particles; (b) the importance of chemical heterogeneity, surface characteristics, size, form, single aerosol vs. cluster configuration, environmental conditions ( $T$, relative humidity, $\mathrm{pH}$, irradiation, etc.) on $\mathrm{CCN}$ or IN ability and the impact of chemical reaction on modification of CCN/IN capability of atmospheric aerosols; (c) the roles of biofilms, viruses and other airborne taxa; (d) the types of chemical feedbacks which microbiology at air/snow/water interfaces supplies to the atmosphere; as well as (e) the nature of chemical mechanism(s) which bio-particles undergo in the atmosphere, and their impacts on the physics and chemistry of the atmosphere.

- Further fundamental laboratory chemical-biological research is required to provide an understanding of the kinetics and mechanisms for chemical transformation by/on bioaerosols including the nature of surfaces, environmental conditions, enzymatic and non-enzymatic transformations, and chemical transformation through non-microbiological processes which are nonetheless invoked by the existence of biological debris.

-We also foresee some need for modeling studies (microphysics, coupled chemistry models at different scales including global climate models) that will ultimately evaluate the role of the bioaerosols.

- Finally, mechanism(s) for atmospheric transport of biological particles should be further considered. Emission, transport, and deposition mechanisms for bioaerosols are to be further studied and an adequate transport model should be evolved.

\section{Acknowledgements}

We would like to thank the Natural Science and Engineering Research Council of Canada (NSERC) and William Dawson chair program for financial support to PAA, and Graydon Snider for many helpful comments on the manuscript.

\section{References}

[1] United Nations Environment Program, Global Environment Outlook: Environment for Development (GEO-4) (UNEP, Nairobi, 2007).

[2] A. Gelencse'r, Carbonaceous Aerosol (Springer, Dordrecht, 2004).

[3] P. Saxena and L.M. Hildemann, J. Atmos. Chem. 24, 57 (1996).

[4] P. A. Ariya and M. Amyot, Atmos. Environ. 38, 1231 (2004).

[5] A. Carvalho, C. Pio, and C. Santos, Atmos. Environ. 37, 1775 (2003).

[6] C. E. Morris, D. C. Sands, M. Bardin, R. Jaenicke, B. Vogel, C. Leyronas, P. A. Ariya, and R. Psenner, Biogeosciences Discuss. 5, 191 (2008).

[7] C. G. Ehrenberg, Abhandlungen d. k. Akad. d. Wissensch. zu Berlin 269 (1849).

[8] R. L. Edmonds and W. S. Benninghoff, U.S. Component of the International Biological Program (Aerobiology Program, 1973).

[9] P. H. Gregory, The Microbiology of the Atmosphere (Interscience Publishers, Inc., New York, 1961).

[10] T. Gidlen, Bio. Rev. 23, 109 (1948).

[11] S. Matthias-Maser, K. Peters, and R. Jaenicke, J. Aerosol. Sci. 26, S545 (1995).

[12] B. Graham, P. Guyon, W. Maenhaut, P. E. Taylor, M. Ebert, S. Matthias-Maser, O. L. MayolBracero, R. H. M. Godoi, P. Artaxo, F. X. Meixner, M. A. Lima Moura, C. H. E. d'Almeida Rocha, R. V. Grieken, M. M. Glovsky, R. C. Flagan, and M. O. Andreae, J. Geophys. Res. 108 (D24), 4765 (2003).

[13] R. Jaenicke, Science 308, 73 (2005).

[14] E. Levetin and K. Dorsey, Aerobiologia 22, 3 (2006).

[15] T. Z. Mitakakis, A. Clift, and P. A. McGee, Grana 40, 230 (2001).

[16] Y. Tong and B. Lighthart, Aerosol Sci. Technol. 32, 393 (2000).

[17] M. Burch and E. Levetin, Int. J. Biometeorol. 46, 107 (2002).

[18] S. L. Maldonado-Ramirez, D. G. Schmale III, E. J. Shields, and G. C. Bergstrom, Agric. For. Meteorol. 132, 20 (2005).

[19] C. A. Kellogg and D. W. Griffin, Trends Ecol. Evol. 21, 638 (2006).

[20] B. Lighthart, FEMS Microbiol. Ecol. 23, 263 (1997).

[21] J. Y. Aller, M. R. Kuznetsova, C. J. Jahns, and P. F. Kemp, J. Aerosol Sci. 36, 801 (2005). [22] C. Leck and K. Bigg, Tellus 57B, 305 (2005). 
This is the peer reviewed version of the following article: [P. A. Ariya, J. Sun, N. A. Eltouny, E. D. Hudson, C. T. Hayes \& G. Kos (2009) Physical and chemical characterization of bioaerosols - Implications for nucleation processes, International Reviews in Physical Chemistry, 28:1, 1-32, DOI: 10.1080/01442350802597438], which is accessible at:

https://www.tandfonline.com/doi/abs/10.1080/01442350802597438

[23] C. E. Morris and J.-M. Monier, Annu. Rev. Phytopathol. 41, 429 (2003).

[24] P. Amato, M. Me'nager, M. Sancelme, P. Laj, G. Mailhot, and A.-M. Delort, Atmos. Environ. 39, 4143 (2005).

[25] J. Sun and P. A. Ariya, Atmos. Environ. 40, 795 (2006).

[26] C. E. Morris, D. Georgakapolous, and D. C. Sands, J. Phys. IV, France 121, 87 (2004).

[27] V. Co`te', G. Kos, R. Mortazavi, and P. A. Ariya, Sci. Total Environ. 390, 530 (2008).

[28] C. E. Morris, L. L. Kinkel, K. Xiao, P. Prior, and D. C. Sands, Infect. Genet. Evol. 7, 84 (2007).

[29] G. Vali, M. Christensen, R. W. Fresh, E. L. Galyan, L. R. Maki, and R. C. Schnell, J. Atmos. Sci. 33, 1565 (1976).

[30] A. M. Jones and R. M. Harrison, Sci. Total Environ. 326, 151 (2004).

[31] V. F. Marchisio, D. Airaudi, and C. Barchi, Mycol. Res. 101, 821 (1997).

[32] F. J. Rodriguez-Rajo, I. Iglesias, and V. Jato, Mycol. Res. 109, 497 (2005).

[33] P.-C. Wu, J.-C. Tsai, F.-C. Li, S.-C. Lung, and H.-J. Su, Atmos. Environ. 38, 4879 (2004). [34] O. Mo"hler, P. J. DeMott, G. Vali, and Z. Levin, Biogeosciences 4, 2551 (2007).

[35] W. Syzrmer and I. Zawadzki, B. Am. Meteorol. Soc. 78, 209 (1997).

[36] H. R. Prupaccher and J. D. Klett, Microphysics of Clouds and Precipitation (Kluwer Academic Publishers, Boston, 1997).

[37] H. Ko" hler, T. Faraday Soc. 32, 1152 (1936).

[38] Z. Varga, G. Kiss, and H.-C. Hansson, Atmos. Chem. Phys. 7, 4601 (2007).

[39] G. Kiss and H.-C. Hansson, Atmos. Chem. Phys. Discuss. 4, 7667 (2004).

[40] K. Diehl, C. Quick, S. Matthias-Maser, S. K. Mitra, and R. Jaenicke, Atmos. Res. 58, 75 (2001).

[41] A. Sengupta, N. Brar, and E. J. Davis, J. Colloid Interface Sci. 309, 36 (2007).

[42] G. Go“tz, E. Me'szaros, and G. Vali, Nucleation of ice (Akade'miai Kiado, Budapest, 1991).

[43] A. J. Heymsfield and R. M. Sabin, J. Atmos. Sci. 46, 2252 (1989).

[44] H. R. Pruppacher, J. Atmos. Sci. 52, 1924 (1994).

[45] G. Vali, Presentation for the NCAR/ASP Summer Colloquium (1999).

[46] M. R. Beaver, M. J. Elrod, R. M. Garland, and M. A. Tolbert, Atmos. Chem. Phys. 6, 3231 (2006).

[47] D. Turnbull and B. Vonnegut, Ind. Eng. Chem. 39, 1125 (1952).

[48] L. H. Seeley and G. T. Seidler, Phys. Rev. Lett. 87, 055702 (2001).

[49] G. M. Bashkirova and P. N. Krasikov, Trudy Glavnoi Geofiz. Obs. 72, 118 (1957).

[50] M. Komabayashi and Y. Ikebe, J. Meteorol. Soc. Jpn. 39, 82 (1961).

[51] N. H. Fletcher, J. Chem. Phys. 38, 237 (1963).

[52] R. B. Head, Nature 191, 1058 (1961).

[53] R. B. Head, J. Phys. Chem. Solids 39, 82 (1962).

[54] N. Fukuta and B. J. Mason, J. Phys. Chem. Solids 24, 715 (1963).

[55] B. Power and R. F. Power, Nature 194, 1170 (1962).

[56] P. Wolber and G. Warren, Trends Biochem. Sci. 14, 179 (1989).

[57] N. Fukuta, J. Atmos. Sci. 23, 191 (1966).

[58] A. Fletcher, J. Appl. Meteorol. 11, 988 (1972).

[59] M. Gavish, R. Popovitzbiro, M. Lahav, and L. Leiserowitz, Science 250, 973 (1990).

[60] R. Popovitzbiro, J. L. Wang, J. Majewski, E. Shavit, L. Leiserowitz, and M. Lahav, J. Amer. Chem. Soc. 116, 1179 (1994).

[61] B. Graham, A. H. Falkovich, Y. Rudich, W. Maenhaut, P. Guyon, and M. O. Andreae, Atmos. Environ. 38, 1593 (2004).

[62] V. Y. Nikandrov, Artificial Actions on Cloud and Fog (Hydrometeorological Publishing House, Leningrad, 1959).

[63] M. Gavish, J. L. Wang, M. Eisenstein, and M. L. Lahav, L., Science 256, 815 (1992).

[64] D. J. Cziczo, P. J. DeMott, S. D. Brooks, A. J. Prenni, D. S. Thomson, D. Baumgardner, J. C. Wilson, S. M. Kreindenweis, and D. M. Murphy, Geophys. Res. Lett. 31, L12116 (2004).

[65] M. E. Wise, R. M. Garland, and M. A. Tolbert, J. Geophys. Res. 109, D19203 (2004).

[66] A. J. Prenni, P. J. DeMott, S. M. Kreidenweis, D. E. Sherman, L. M. Russell, and Y. Ming, J. Phys. Chem. A 105, 11240 (2001).

[67] B. Karcher and T. Koop, Atmos. Chem. Phys. 5, 703 (2005).

[68] J. E. Shilling, T. J. Fortin, and M. A. Tolbert, J. Geophys. Res.-Atmos. 111, D12204 (2006). [69] B. Zobrist, C. Marcolli, T. Koop, B. P. Luo, D. M. Murphy, U. Lohmann, A. A. Zardini, U. K. Krieger, T. Corti, D. J. Cziczo, S. Fueglistaler, P. K. Hudson, et al., Atmos. Chem. Phys. 6, 3115 (2006).

[70] T. W. Choularton, K. N. Bower, E. Weingartner, I. Crawford, H. Coe, M. W. Gallagher, M. Flynn, J. Crosier, P. Connolly, A. Targino, M. R. Alfarra, U. Baltensperger, et al., Faraday Discuss. 137, 205 (2008).

[71] J. Hallet and S. Mossop, Nature 249, 23 (1974).

[72] P. J. DeMott, Atmos. Res. 38, 63 (1995).

[73] G. Vali, Am. J. Phys. 39, 1125 (1971).

[74] B. Kra“mer, O. Hu"bner, H. Vortisch, L. Wo“ste, and T. Leisner, J. Chem. Phys. 111, 6521 (1999).

[75] R. Chow, R. Blindt, R. Chivers, and M. Povey, Ultrasonics 43, 227 (2005).

[76] S. J. Gallavardin, K. D. Froyd, U. Lohmann, O. Moehler, D. M. Murphy, and D. J. Cziczo, Aerosol Sci. Technol. 42,773 (2008).

[77] F. Zimmerman, M. Ebert, A. Worrengen, L. Schu"tz, and S. Weinbruk, Atmos. Environ. 41, 8219 (2007).

[78] Hygroscopic in Van Nostrand's Scientific Encyclopedia edited by G. D. Considine. 9th ed (John Wiley \& Sons, Inc., New York, 2002$),$ Vol. 1 pp. 1885.

[79] I. Salma, R. Ocskay, I. Varga, and W. Maenhaut, J. Geophys. Res. 111, D23205 (2006). [80] K. E. Yttri, C. Dye, and G. Kiss, Atmos. Chem. Phys. 7, 4267 (2007).

[81] H. Bauer, A. Kasper-Giebl, H. Loflund, H. Giebl, R. Hitzenberger, F. Zibuschka, and H. Puxbaum, Atmos. Res. 64, 100 (2002).

[82] M. Kanakidou, J. H. Seinfeld, S. N. Pandis, I. Barnes, F. J. Dentener, M. C. Facchini, R. van Dingenen, B. Ervens, A. Nenes, C. J. Nielsen, E. Swietlicki, J. P. Putaud, et al., Atmos. Chem. Phys. 5, 1053 (2005).

[83] R. Jaenicke, Science 308, 73 (2005).

[84] A. Gelencse'r, B. May, D. Simpson, A. Sánchez-Ochoa, A. Kasper-Giebl, H. Puxbaum, A. Caseiro, C. Pio, and M. Legrand, J. Geophys. Res. 112, D23SO4 (2007). 
This is the peer reviewed version of the following article: [P. A. Ariya, J. Sun, N. A. Eltouny, E. D. Hudson, C. T. Hayes \& G. Kos (2009) Physical and chemical characterization of bioaerosols - Implications for nucleation processes, International Reviews in Physical Chemistry, 28:1, 1-32, DOI: 10.1080/01442350802597438], which is accessible at:

https://www.tandfonline.com/doi/abs/10.1080/01442350802597438

[85] Z. Kriva'csy, A. Gelencse'r, G. Kiss, E. Me'sza'ros, A' . Molnár, A. Hoffer, T. Me'sza'́ros, Z. Sa'rva'ri, D. Temesi, B. Varga, U. Baltensperger, S. Nyeki, et al., J. Atmos. Chem. 39, 235 (2001).

[86] E. R. Graber and Y. Rudich, Atmos. Chem. Phys. 6, 729 (2006).

[87] M. Claeys, B. Graham, G. Vas, W. Wang, R. Vermeylen, V. Pashynska, J. Cafmeyer, P. Guyon, M. O. Andreae, P. Artaxo, and W. Maenhaut, Science 303, 1173 (2004)

[88] E. Dinar, I. Taraniuk, E. R. Graber, S. Katsman, T. Moise, T. Anttila, T. F. Mentel, and Y. Rudich, Atmos. Chem. Phys. 6, 2465 (2006).

[89] H. Bauer, H. Giebl, R. Hitzenberger, A. Kasper-Giebl, G. Reischl, F. Zibuschka, and H. Puxbaum, J. Geophys. Res.-Atmos. 108, 4658 (2003).

[90] S. N. Pandis and J. H. Seinfeld, Atmospheric Chemistry and Physics (Wiley-Interscience Publication, New York, 1998).

[91] T. M. Raymond and S. N. Pandis, J. Geophys. Res. 107, 1759 (2002).

[92] F. K. Skinner, Y. Rotenberg, and A. W. Neumann, J. Colloid Interface Sci. 130, 25 (1989). [93] F. M. Bowman and J. A. Melton, J. Aerosol Sci. 35, 1415 (2004)

[94] M. Y. Choi and C. K. Chan, J. Phys. Chem. A 106, 4566 (2002).

[95] C. Tong, S. L. Clegg, and J. H. Seinfeld, Atmos. Environ. 42, 5459 (2008).

[96] L.M.R. Yi Ming, AlChE J. 48, 1331 (2002).

[97] L. Deguillaume, M. Leriche, P. Amato, P. A. Ariya, A.-M. Delort, U. Po“schl, N. Chaumerliac, H. Bauer, A. I. Flossmann, and C. E. Morris, Biogeosciences 5, 1073 (2008).

[98] Y. Rudich, N. M. Donahue, and T. F. Mentel, Annu. Rev. Phys. Chem. 58, 321 (2006).

[99] S. Fuzzi, M. O. Andreae, B. J. Huebert, M. Kulmala, T. C. Bond, M. Boy, S. J. Doherty, A. Guenther, M. Kanakidou, K. Kawamura, V. M. Kerminen, U. Lohmann, et al., Atmos. Chem. Phys. 6, 2017 (2006).

[100] A. Plewka, T. Gnauk, E. Bruggemann, and H. Herrmann, Atmos. Environ. 40, S103 (2006).

[101] D. A. Knopf, L. M. Anthony, and A. K. Bertram, J. Phys. Chem. A 109, 5579 (2005). [102] D. G. Georgakopoulos, V. Despre's, J. Fro“hlichNowoisky, R. Psenner, P. A. Ariya, M. Posfai, H. E. Ahern, B. F. Moffett, and T. C. J. Hill, Biogeosciences Discuss. 5, 1469 (2008). [103] K. Wittmaack, H. Wehnes, U. Heinzmann, and R. Agerer, Sci. Total Environ. 346, 244 (2005).

[104] M. Posfai, J. Li, J. R. Anderson, and P. R. Buseck, Atmos. Res. 66, 231 (2003).

[105] M. Glikson, S. Rutherford, R. W. Simpson, C. A. Mitchell, and A. Yago, Atmos. Environ. 29, 549 (1995).

[106] K. Wittmaack, Atmos. Environ. 39, 1173 (2005).

[107] S. Yadav, M. S. Chauhan, and A. Sharma, Atmos. Environ. 41, 6063 (2007).

[108] G. A. Czerwieniec, S. C. Russell, C. B. Lebrilla, K. R. Coffee, V. Riot, P. T. Steele, M. Frank, and E. E. Gard, J. Am. Soc. Mass Spectrom. 16,1866 (2005).

[109] D. P. Fergenson, M. E. Pitesky, H. J. Tobias, P. T. Steele, G. A. Czerwieniec, S. C. Russell, C. B. Lebrilla, J. M. Horn, K. R. Coffee, A. Srivastava, S. P. Pillai, M. T. P. Shih, et al., Anal. Chem. 76, 373 (2004).

[110] G. A. Czerwieniec, S. C. Russell, H. J. Tobias, M. E. Pitesky, D. P. Fergenson, P. Steele, A. Srivastava, J. M. Horn, M. Frank, E. E. Gard, and C. B. Lebrilla, Anal. Chem. 77, 1081 (2005).

[111] I. Kleefsman, M. A. Stowers, P. J. T. Verheijen, A.L. Van Wuijckhuijse, C. E. Kientz, and J. C. M. Marijnissen, Part. Part. Syst. Char. 24, 85 (2007)

[112] P. Rosch, M. Harz, K. D. Peschke, O. Ronneberger, H. Burkhardt, A. Schule, G. Schmauz, M. Lankers, S. Hofer, H. Thiele, H. W. Motzkus, and J. Popp, Anal. Chem. 78, 2163 (2006). [113] K. Kawamura, A. Yanase, T. Eguchi, T. Mikami, and L. A. Barrie, Geophys. Res. Lett. 23,3735 (1996).

[114] C. Alves, C. Pio, and A. Duarte, Atmos. Environ. 35, 5485 (2001).

[115] S. G. Brown, P. Herckes, L. Ashbaugh, M. P. Hannigan, S. M. Kreidenweis, and J. L. Collett, Atmos. Environ. 36,5807 (2002).

[116] A. I. Gogou, M. Apostolaki, and E. G. Stephanou, J. Chromatogr. A 799, 215 (1998).

[117] C. Pio, C. Alves, and A. Duarte, Atmos. Environ. 35, 389 (2001).

[118] B. R. T. Simoneit, J. J. Schauer, C. G. Nolte, D. R. Oros, V. O. Elias, M. P. Fraser, W. F. Rogge, and G. R. Cass, Atmos. Environ. 33,173 (1999).

[119] B. Graham, O. L. Mayol-Bracero, P. Guyon, G. C. Roberts, S. Decesari, M. C. Facchini, P. Artaxo, W. Maenhaut, P. Koll, and M. O. Andreae, J. Geophys. Res. 107, 8047 (2002).

[120] A. Kubatova, R. Vermeylen, M. Claeys, J. Cafmeyer, and W. Maenhaut, J. Geophys. Res. 107, 8343 (2002).

[121] R. J. Sheesley, J. J. Schauer, Z. Chowdhury, G. R. Cass, and B. R. T. Simoneit, J. Geophys. Res. 108, 4285 (2003).

[122] B. R. T. Simoneit, J. N. Cardoso, and N. Robinson, Chemosphere 23, 447 (1991).

[123] C. A. Pio, C. A. Alves, and A. C. Duarte, Atmos. Environ. 35, 1365 (2001).

[124] K. Kawamura, Y. Ishimura, and K. Yamazaki, Global Biogeochem. Cycles 17, 1003 (2003).

[125] B. R. T. Simoneit and V. O. Elias, Mar. Chem. 69, 301 (2000).

[126] M. K. Shrivastava, R. Subramanian, W. F. Rogge, and A. L. Robinson, Atmos. Environ. 41, 9353 (2007).

[127] E. C. H. Wan and J. Z. Yu, Environ. Sci. Technol. 41, 2459 (2007).

[128] J. Warnke, R. Bandur, and T. Hoffmann, Anal. Bioanal.Chem. 385, 34 (2006).

[129] Y. Iinuma, C. Muller, T. Berndt, O. Boge, M. Claeys, and H. Herrmann, Environ. Sci. Technol. 41, 6678 (2007).

[130] C. Dye and K. E. Yttri, Anal. Chem. 77, 1853 (2005).

[131] D. Van Pinxteren and H. Herrmann, J. Chromatogr. A 1171, 112 (2007).

[132] N. Havers, P. Burba, D. Klockow, and A. Klockow-Beck, Chromatographia 47, 619 (1998).

[133] R. Seco, J. Penuelas, and I. Filella, Atmos. Environ. 41, 2477 (2007).

[134] I. G. Kavouras, N. Mihalopoulos, and E. G. Stephanou, Nature 395, 683 (1998).

[135] A. Chebbi and P. Carlier, Atmos. Environ. 30, 4233 (1996).

[136] S. Yu, Atmos. Res. 53, 185 (2000).

[137] A. G. Allen, A. A. Cardoso, and G. O. da Rocha, Atmos. Environ. 38, 5025 (2004).

[138] J. G. Brooks Avery, R. J. Kieber, M. Witt, and J. D. Willey, Atmos. Environ. 40, 1683 (2006).

[139] M. Kunit and H. Puxbaum, Atmos. Environ. 30, 1233 (1996).

[140] H. Puxbaum and M. Tenze-Kunit, Atmos. Environ. 37, 3693 (2003).

[141] Y. L. Pan, R. G. Pinnick, S. C. Hill, J. M. Rosen, and R. K. Chang, J. Geophys. Res.-Atmos. 112, D24519 (2007). 
This is the peer reviewed version of the following article: [P. A. Ariya, J. Sun, N. A. Eltouny, E. D. Hudson, C. T. Hayes \& G. Kos (2009) Physical and chemical characterization of bioaerosols - Implications for nucleation processes, International Reviews in Physical Chemistry, 28:1, 1-32, DOI: 10.1080/01442350802597438], which is accessible at:

https://www.tandfonline.com/doi/abs/10.1080/01442350802597438

[142] R. G. Pinnick, S. C. Hill, Y.-L. Pan, and R. K. Chang, Atmos. Environ. 38, 1657 (2004). [143] G. Kiss, E. Tombacz, B. Varga, T. Alsberg, and L. Persson, Atmos. Environ. 37, 3783 (2003).

[144] Z. D. Li, A. L. Williams, and M. J. Rood, J. Atmos. Sci. 55, 1859 (1998).

[145] E. Dinar, I. Taraniuk, E. R. Graber, T. Anttila, T. F. Mentel, and Y. Rudich, J. Geophys. Res. 112, D05211 (2007).

[146] M. N. Chan, S. M. Kreidenweis, and C. K. Chan, Environ. Sci. Technol. 42, 3602 (2008). [147] H. Tervahattu, K. Hartonen, V. M. Kerminen, K. Kupiainen, P. Aarnio, T. Koskentalo, A. F. Tuck, and V. Vaida, J. Geophys. Res. 107, 4053 (2002).

[148] H. Tervahattu, J. Juhanoja, and K. Kupiainen, J. Geophys. Res.-Atmos. 107, 4319 (2002). [149] K. Diehl and S. Wurzler, J. Atmos. Sci. 61, 2063 (2004).

[150] S. Fuzzi, P. Mandrioli, and A. Perfetto, Atmos. Environ. 31, 287 (1997).

[151] B. Sattler, H. Puxbaum, and R. Psenner, Geophys.Res.Lett. 28, 239 (2001).

[152] L. R. Maki and J. Willoughby, J. Appl. Meteorol. 17, 1049 (1978).

[153] B. C. Parker, Nature 219, 617 (1968). [154] P. Mandrioli, G. K. Puppi, N. Bagni, and F. Prodi, Nature 246, 416 (1973). [155] Y. Tong and B. Lighthart, Aerosol Sci. Technol. 30, 246 (1999). [156] V. I. Borodulin, Y. S. Kachanov, and A. P. Roshchektaev, Thermophysics and Aeromechanics 10, 1 (2003). [157] D. C. Sands, V. E. Langhans, A. L. Scharen, and G. de Smet, Idojaras 86, 148 (1992).

[158] J. Lindemann, H. A. Constantinidou, W. R. Barchet, and C. D. Upper, Appl. Environ. Microbiol. 44, 1059 (1982).

[159] J. Lindemann and C. D. Upper, Appl. Environ. Microbiol. 50, 1229 (1985).

[160] H. A. Constantinidou, S. S. Hirano, L. S. Baker, and C. D. Upper, Phytopathology 80, 934 (1990).

[161] K. Diehl, M. Simmel, and S. Wurzler, J. Geophys. Res. 111, D07202 (2006).

[162] J. Sun, P. A. Ariya, H. G. Leighton, and M. K. Yau, J. Atmos. Sci. (in preparation).

[163] J. Sun, P. A. Ariya, H. G. Leighton, and M. K. Yau, Geophys. Res. Lett. (submitted).

[164] P. Forster, V. Ramaswamy, P. Artaxo, T. Berntsen, R. Betts, D. W. Fahey, J. Haywood, J. Lean, D. C. Lowe, G. Myhre, J. Nganga, R. Prinn et al., IPCC Fourth assessment Report: Climate Change 2007, 2007.

[165] S. Yu, R. L. Dennis, P. V. Bhave, and B. K. Eder, Atmos. Environ. 38, 5257 (2004).

[166] W. Winiwarter, H. Bauer, A. Caseiro, and H. Puxbaum, Atmos. Environ. In Press, (2008). [167] J. E. Penner, M. Andreae, H. Annegarn, L. Barrie, J. Feichter, D. Hegg, A. Jayaraman, R. Leaitch, D. Murphy, J. Nganga, G. Pitari, A. Ackerman, et al., in Climate Change 2001: The Scientific Basis. Contribution of Working Group I to the Third Assessment Report of the Intergovernmental Panel on Climate Change, edited by J. T. Houghton, Y. Ding, D. J. Griggs, et al. (Cambridge University Press, Cambridge, 2001).

[168] D. G. Nash, T. Baer, and M. V. Johnston, Int. J. Mass Spectrom. 258, 2 (2006).

[169] F. Drewnick, J. Schneider, S. S. Hings, N. Hock, K. Noone, A. Targino, S. Weimer, and S. Borrmann, J. Atmos. Chem. 56, 1 (2007).

[170] T. Anttila, A. Kiendler-Scharr, T. F. Mentel, and R. Tillmann, J. Atmos. Chem. 57, 215 (2007).

[171] G. A. Czerwieniec, S. C. Russell, H. J. Tobias, M. E. Pitesky, D. P. Fergenson, P. Steele, A. Srivastava, J. M. Horn, M. Frank, E. E. Gard, and C. B. Lebrilla, Anal. Chem. 77, 1081 (2005).

[172] D. P. Fergenson, M. E. Pitesky, H. J. Tobias, P. T. Steele, G. A. Czerwieniec, S. C. Russell, C. B. Lebrilla, J. M. Horn, K. R. Coffee, A. Srivastava, S. P. Pillai, M. T. P. Shih, et al., Anal. Chem. 76, 373 (2004).

[173] L. R. Maki, E. L. Gaylan, M. Chang-Chien, and D. R. Caldwell, Appl. Microbiol. 28, 456 (1974).

[174] L. M. Kozloff, M. A. Schofield, and M. Lute, J. Bacteriol. 153, 222 (1983).

[175] J. S. Rogers, R. E. Stall, and M. J. Burke, Cryobiology 24, 270 (1987).

[176] M. Fukata, J. Atmos. Sci. 32, 1597 (1975).

[177] R. A. Shaw, A. J. Dourant, and Y. Mi, J. Phys. Chem. B 109, 9865 (2005).

[178] R. C. Schaller and N. Fukata, J. Atmos. Sci. 36, 1788 (1979).

[179] A. Salam, U. Lohmann, B. Crenna, G. Lesins, P. Kleges, D. Rogers, R. Irani, A. MacGillvray, and P. Coffin, Aerosol Sci. Technol. 40, 134 (2006).

[180] M. Ettner, S. K. Mitra, and S. Borrman, Atmos. Chem. Phys. 4, 1925 (2004).

[181] S. E. Wood, M. B. Baker, and B. D. Swanson, Rev. Sci. Instrum. 73, 3988 (2002).

[182] K. Diehl, S. Matthias-Maser, S. K. Mitra, and R. Jaenicke, Atmos. Res. 61, 125 (2002). [183] R. L. Pitter and H. R. Pruppacher, Q. J. Roy. Meteor. Soc. 99, 540 (1973).

[184] C. N. Cruz and S. N. Pandis, Environ. Sci. Technol. 34, 4313 (2000).

[185] I. Varga, T. Keszthelyi, R. Meszaros, O. Hakkel, and T. Gilanyi, J. Phys. Chem. B 109, 872 (2005).

[186] W. E. Asher, J. F. Pankow, G. B. Erdakos, and J. H. Seinfeld, Atmos. Environ. 36, 1483 (2002).

[187] M. Kallio, M. Jussila, T. Rissanen, P. Anttila, K. Hartonen, A. Reissell, R. Vreuls, M. Adahchour, and T. Hyotylainen, J. Chromatogr. A 1125, 234 (2006).

[188] B. Chandramouli, M. Jang, and R. M. Kamens, Atmos. Environ. 37, 835 (2003).

[189] M. C. Jacobson, H. C. Hansson, K. J. Noone, and R. J. Charlson, Rev. Geophys. 38, 267 (2000).

[190] T. Asai and A. Kasahara, J. Atmos. Sci. 24, 487 (1967).

[191] M. K. Yau, J. Atmos. Sci. 37, 2470 (1980).

[192] R. Wilhelmson and Y. Ogura, J. Atmos. Sci. 29, 1295 (1972).

[193] H. R. Pruppaccher and J. D. Klett, Microphysics of Clouds and Precipitation (Kluwer Academic Publishers, Boston, 1997).

[194] N. A. Berezinski, G. V. Stepanov, and V. G. Khorguani, in Atmospheric aerosols and Nucleation, edited by P. E. Wagner and G. Vali (Springer, New York, 1988).

[195] G. D. Franc and P. J. DeMott, J. Appl. Meteorol. 37, 1293 (1998).

[196] Y. Qian, K. Willeke, V. Ulevicius, S. A. Grinshpun, and J. Donnelly, Atmos. Environ. 29, 1123 (1995).

\section{Appendix}


This is the peer reviewed version of the following article: [P. A. Ariya, J. Sun, N. A. Eltouny, E. D. Hudson, C. T. Hayes \& G. Kos (2009) Physical and chemical characterization of bioaerosols - Implications for nucleation processes, International Reviews in Physical Chemistry, 28:1, 1-32, DOI: 10.1080/01442350802597438], which is accessible at:

https://www.tandfonline.com/doi/abs/10.1080/01442350802597438

\section{Formation of a non-hydrostatic two-cylinder model}

A low-dimensional model can be applied to test the complex liquid-phase and ice-phase microphysical processes. For this reason, we chose a one-and-a-half-dimensional model. The first cylindrical model was presented by Asai and Kasahara $\underline{190}$ to investigate the influence of compensating downward motions on cumulus cloud formation and evolution. In such a model, two circular concentric air columns describe the updraft/cloud region (inside column) and the compensating downward motion region (outside column). This model also allows us to describe the exchange processes between the lateral sides of the two cylinders. Yau 191 presented a method to include explicit computations of perturbation pressures, which resolved the modeling problem of an unrealistically large gradient of vertical velocities at the top of simulated cumulus clouds. We further thoroughly modified the diagnostic method of computing the perturbation pressure force by assuming that horizontally, the vertical wind velocities are distributed sinusoidally in cumulus clouds. Vertical eddy fluxes were also calculated in order to consider the changes of the vertical distribution of aerosols and hydrometeors induced by wind velocity deformation and thermal instability.

\section{Case study}

The initial thermodynamic conditions for the simulation of this case were the same as those used by Yau 191 to represent idealized sounding conditions of cumulus clouds. However, we modified the temperature profile from 6 to $5.7^{\circ} \mathrm{C} \mathrm{km}^{-1}$ above cloud base to ensure the temperature of the cloud top around $-10^{\circ} \mathrm{C}$. The temperatures at the sea surface and at the cloud base $(800 \mathrm{~m})$ were 24 and $17^{\circ} \mathrm{C}$, respectively. In our study, the vertically horizontal wind shear was not considered. The calculation method of initial pressure is given by Wilhelmson and Ogura $\underline{192}$. The first calculation of pressure is made without considering the vapor effect in the hydrostatic equation, assuming a $1000 \mathrm{mb}$ pressure level at $z=0, q_{\mathrm{v}}$ is then determined; and the second calculation of pressure includes the $q_{\mathrm{v}}$ term.

$$
\frac{\partial \ln p}{\partial z}=\frac{g}{R T\left(1+0.608 q_{v}\right)}
$$

The tripled maritime aerosol concentration and distribution were used in this case study. The initial aerosol concentrations decreased exponentially with height above cloud base. The initial drop sizes are determined by classical Kohler theory $\underline{193}$. The maximum size of haze drops is calculated in equilibrium at $99 \%$ relative humidity at the cloud base. To initiate convection, we use a perturbation of vertical velocity to start our model. The initial vertical velocity impulse is assumed to be

$$
W(z)=\sin (\pi z / 2), \quad z<0.8 \mathrm{~km}
$$

In the ice initiation process, primary ice crystals are nucleated through the immersion mode. The concentrations of primary ice crystals depend on the ice-nucleation ability of bacteria. The concentration of ice-nucleating bacteria is assumed to be $0.36 \mathrm{~L} 1$ measured by Berezinski et al. [194] at a temperature of 12C, and linearly decreases to zero at the cloud base. In the immersion mode, the size of bioaerosol-containing droplets is one important factor affecting their nucleation rate and their scavenging. Note that the initial size distribution of IN influences their sizes in addition to the collision and coalescence processes with water droplets. The size distribution and hygroscopicity of IN impact their collision efficiency with hydrometeors. Both their size distribution [16] and their activation as cloud condensation nuclei [195] are taken into account in our study. The size distribution of IN is selected to be the same as a combination of two measured bacterial size distributions [16,196] and the concentration of single cell particles is $40 \%$ of the total particles. 